\title{
Current distribution and potential expansion of the harmful benthic dinoflagellate Ostreopsis cf. siamensis towards the warming waters of the Bay of Biscay, NorthEast Atlantic
}

Drouet Kevin 1, 2, Jauzein Cecile ${ }^{2}$, Hervio Heath Dominique ${ }^{3}$, Hariri Saeed ${ }^{2}$, Laza-martinez A. 4, 5 , Lecadet Cyrielle ${ }^{6}$, Plus Martin ${ }^{2}$, Seoane S. ${ }^{4,5}$, Sourisseau Marc ${ }^{2}$, Lemée R. ${ }^{1}$, Siano Raffaele ${ }^{2,}$ *

${ }^{1}$ Sorbonne Université, CNRS - Laboratoire d'Océanographie de Villefranche (UMR 7093) -

Villefranche-sur-mer 06230, France

2 Ifremer, DYNECO - F-29280 Plouzané, France

3 Ifremer PFOM - F-29280 Plouzané, France

${ }^{4}$ Department of Plant Biology and Ecology - University of the Basque Country UPV/EHU - Leioa 48940, Spain

${ }^{5}$ Research Centre for Experimental Marine Biology and Biotechnology (Plentzia Marine Station, PiE-

UPV/EHU) - Plentzia 48620, Spain

${ }^{6}$ Ifremer, LGPMM - F-17390 La Tremblade, France

*Corresponding author : Raffaele Siano, email address : raffaele.siano@ifremer.fr

\begin{abstract}
:
In a future scenario of increasing temperatures in North-Atlantic waters, the risk associated with the expansion of the harmful, benthic dinoflagellate Ostreopsis cf. siamensis has to be evaluated and monitored. Microscopy observations and spatio-temporal surveys of environmental DNA (eDNA) were associated with Lagrangian particle dispersal simulations to: i) establish the current colonization of the species in the Bay of Biscay, ii) assess the spatial connectivity among sampling zones that explain this distribution, iii) identify sentinel zones to monitor future expansion. Throughout a sampling campaign carried out in August-September 2018, microscope analysis showed that the species develops in the south-east of the bay where optimal temperatures foster blooms. Quantitative PCR analyses revealed its presence across almost the whole bay to the western English Channel. An eDNA time-series collected on plastic samplers showed that the species occurs in the bay from April to September. Due to the water circulation, colonization of the whole bay from the southern blooming zones is explained by inter-site connectivity. Key areas in the middle of the bay permit continuous dispersal connectivity towards the north. These key areas are proposed as sentinel zones to monitor $\mathrm{O}$. cf. siamensis invasions towards the presumably warming water of the North-East Atlantic.
\end{abstract}

Keywords : Climate change, Harmful Algal Blooms, Dinoflagellate, Invasive species, Environmental DNA, Real-time PCR, Lagrangian modeling, Risk management 


\section{Introduction}

Climate change is considered to be a driver of marine species distribution (Perry, 2005; Thomas et al., 2012). In a future scenario of seawater temperature increase, the expansion of harmful algae into new areas (Hallegraeff, 2010; Kudela and Gobler, 2012; McLeod et al., 2012; Gobler, 2020; Tester et al., 2020) and changes in their seasonal occurrences are expected (Moore et al., 2008; Ralston et al., 2014; Nakada et al., 2018). Harmful algal blooms (HABs) refer to the development of noxious phytoplankton species at levels causing deleterious impacts on humans or marine biota. Risks to human health are generally associated with the consumption of contaminated seafood (Jeffery et al., 2004; Etheridge, 2010) and direct toxin exposure to cells or aerosols (Cheng et al., 2005). Fauna and flora mortality could be linked to toxin exposure, but also to hypoxia or anoxia due to bacterial degradation after the bloom (Pitcher and Probyn, 2011; Lim et al., 2014). In recent decades, reports of HABs events have been increasing (Shears and Ross, 2009; Hallegraeff, 2010; Berdalet, Tester, et al., 2017), raising awareness of sanitary, economic and ecological impacts. Despite discussions on the of the reliability of this increase are still ongoing (Hallegraeff 1993; Zingone et al 2020), HAB intensification has been suspected to be linked to a combination of factors such as climate change (Moore et al., 2008; Glibert et al., 2014; Kibler et al., 2015; Wells and Karlson, 2018; Tester et al., 2020), anthropogenic eutrophication (Glibert et al., 2005; Heisler et al., 2008; Davidson et al., 2014), ballast water dispersion (Hallegraeff and Bolch, 1991; Smayda, 2007) and the worldwide improvement in knowledge and monitoring of HABs (Van Dolah, 2000; Anderson, 2009; Anderson et al., 2012). Given the key role played by temperature in the growth and distribution of marine phytoplankton (Eppley, 1972; Wells et al., 2015), HAB geographic ranges are expected to expand in temperate zones (Paerl and Paul, 2012; Carnicer et al., 2016; Gobler et al., 2017). For instance, Kudela and Gobler (2012) witnessed the recent global expansion of Cochlodinium sp. while Vandersea et al. (2018) observed an increase in Alexandrium catenella blooms associated with positive sea surface temperature anomalies $\left(>1-2^{\circ} \mathrm{C}\right)$ in the Gulf of Alaska. The potential global expansion of HAB species due to climate change

This article is protected by copyright. All rights reserved. 
represents a threat to human health and marine ecosystems and risk assessment is essential for effective management (Berdalet et al., 2017; Brown et al., 2019).

The benthic dinoflagellate genus Ostreopsis Schmidt (1901) is considered to be a case study regarding the impact of climate change on harmful algal species (Tester et al., 2020). Its expansion beyond the genus's traditional geographical range due to ocean warming is expected in temperate regions where specific habitat requirement are met (Tester et al., 2020). Although Ostreopsis species have been detected in relatively cold waters, blooms of this genus have mostly been observed across the world in warm waters of tropical and temperate regions (Shears and Ross, 2009; Rhodes, 2011; Selina et al., 2014), notably in the Mediterranean Sea (Mangialajo et al., 2011; Blanfuné et al., 2015; Accoroni and Totti, 2016). Toxic outbreaks resulting from some Ostreopsis species blooms affect human health through direct contact, inducing skin irritation (Tichadou et al., 2010; Tubaro et al., 2011), or through inhalation of aerosols, responsible for serious respiratory symptoms (Durando et al., 2007; Vila et al., 2016), presumably linked to the production of toxins belonging to the palytoxin group (Ciminiello et al., 2006, 2012, 2014; Sechet et al., 2012). While the genus is relatively easy to detect morphologically, with observation using light microscopy, identification at species level can be difficult because unambiguous morphological synapomorphies seem elusive. Eleven named Ostreopsis species have been described so far but the high degree of morphological variability within the same species (Parsons et al., 2012; Chomérat et al., 2019) makes genetic identification essential and complicates phylogeographical and species-specific studies (Penna et al., 2010; Verma et al., 2016; Zhang et al., 2018; Chomérat et al., 2020). Analysis of the global distribution of Ostreopsis species is even more problematic considering that molecular clades have been associated with geographical distribution (Penna et al., 2010, 2014; Sato et al., 2011; Tawong et al., 2014), highlighting a cryptic distributional pattern of Ostreopsis species around the world.

This genetic clade-specific distribution has been reported for the type species Ostreopsis siamensis Schmidt, which was first described in the tropical waters of the Gulf of Siam (Thailand) (Schmidt 1901), but never genetically characterized. Since then, isolates morphologically attributable 
to 0 . siamensis have been detected in tropical, sub-tropical and temperate areas in the Atlantic, Pacific and Indian Oceans (Faust et al., 1996; Rhodes, 2011). The taxonomic classification "O. cf. siamensis" is conventionally used in the literature, although no sequences from this clade have been clustered with O. siamensis strains recently isolated in areas close to the Gulf of Siam (Tawong et al., 2014; Chomérat et al., 2019). The latitudinal distribution of the clade $O$. cf. siamensis across the world seems to be limited to between the $43^{\text {rd }}$ and $44^{\text {th }}$ parallel in the northern hemisphere, where it has been detected in the north-western Mediterranean Sea (Mangialajo et al., 2008) and in north-eastern Atlantic (LazaMartinez et al., 2011), and to the $41^{\text {st }}$ parallel in the southern hemisphere in New-Zealand and Tasmania (Pearce et al., 2001; Shears and Ross, 2009). In the north-eastern Atlantic, both O. cf. ovata and $O$. cf. siamensis have been observed along the south-western coasts of the Atlantic Iberian Peninsula (Amorim et al., 2010; Santos et al., 2019), but only O. cf. siamensis has been observed in the northern part of the coast line of the Cantabrian Sea, located in the south of the Bay of Biscay (LazaMartinez et al., 2011; David et al., 2013; Seoane and Siano, 2018). To date, no survey of Ostreopsis species across the whole of the Bay of Biscay has been performed. This tide-affected bay, exposed to ocean warming (deCastro et al., 2009; Costoya et al., 2016), represents a key zone in monitoring potential Ostreopsis spp. expansion into warming waters. Hence, this zone in the future could offer new ecological niches for Ostreopsis species. Moreover, this area offers favorable habitats for Ostreopsis spp. settlement and development, such as shallow and sheltered habitats where wide ramified macroalgae coverage serves as biotic substrate (Vila et al., 2001; Totti et al., 2010; Cohu et al., 2013). Although $O$. cf. siamensis toxicity bioassays have revealed a toxic effect in Mediterranean and Atlantic strains (Cagide et al., 2009; Laza-Martinez et al., 2011) potentially imputed to the production of palytoxin-like compounds, traces of these analogs have been exclusively found in SouthEast Australian strains (Ciminiello et al., 2013; Verma et al., 2016). Hence, other non-identified potentially toxic compounds could thus be responsible for $O$. cf. siamensis toxicity. Although its toxicity is less studied than that of $O$. cf. ovata (Pavaux et al., 2020), O. cf. siamensis is still considered a potentially $\mathrm{HAB}$ risk species worldwide.

This article is protected by copyright. All rights reserved. 
Monitoring of Ostreopsis spp. has generally been conducted through benthic sampling of macroalgae followed by light microscopy observation of epiphytic cells (Jauzein et al., 2018). However, this method seems inadequate in areas where cells are not abundant enough to be easily detected. Molecular methods based on the analysis of environmental DNA (eDNA) are now used to detect the presence of rare species of microorganisms, especially for the conservation and monitoring of endangered species (Jerde et al., 2011; Taberlet et al., 2012; Thomsen and Willerslev, 2015; Barnes and Turner, 2016), but also for monitoring harmful algal species (Galluzzi et al., 2004; Fitzpatrick et al., 2010; Garvetto et al., 2018; Huang et al., 2019). Standard and quantitative real time PCR or quantitative (rt-PCR or qPCR) methods, based on the analysis of species-specific Internal Transcribed Spacer (ITS)5.8S and Large Sub Unit (LSU) ribosomal DNA, have been developed and applied to the monitoring of Ostreopsis species (Penna et al., 2007; Battocchi et al., 2010; Casabianca et al., 2013, 2014). However, when dealing with eDNA-based monitoring approaches for species repartition assessment, the origins of intracellular DNA (DNA extracted from cells) or extracellular DNA (free DNA molecules derived from cell lysis) and its degree of persistence in marine environments are key issues that could complicate the interpretation of genetic surveys.

Ostreopsis species are tychoplanktonic microorganisms, which means that cells can be resuspended in the water column from their substrates and hydrodynamically dispersed. The dispersal and introduction of planktonic cells into new environments can then be achieved by water mass dynamics and currents (Coleman et al., 2013). The advection of water parcels is responsible for the connectivity of different physical environments (Jönsson and Watson, 2016) and constrains the biogeographic distribution of planktonic species (Treml et al., 2008; McManus and Woodson, 2012; Ginders et al., 2016). Species dispersal areas can be investigated through particle transport modeling. In particular, the Lagrangian approach can be used to identify the temporal and spatial trajectories of planktonic organisms (van Sebille et al., 2018). Therefore, this approach seems appropriate for the study of Ostreopsis spp. dispersal in its planktonic stage form.

This article is protected by copyright. All rights reserved. 
In order to monitor the expansion of Ostreospis spp. towards the potentially warming waters of the NE Atlantic, the first baseline distribution survey of Ostreopsis spp. in the Bay of Biscay was carried out to detect its presence, even under very low levels of abundance. Areas favorable to $O$. cf. siamensis development and areas likely to be colonized due to water mass advection were identified using a Lagrangian approach. The innovative association between eDNA monitoring and hydrological connectivity has enabled the identification of sentinel zones to monitor potential future expansion and development of the species in relation to climate changes.

\section{Results}

\section{Light microscopy analysis of fixed samples}

The presence of epiphytic Ostreopsis spp. cells was analyzed from macroalgae samples collected in the 40 sampling sites (Fig. 1, Table 1) of the spatial survey carried on in the Bay of Biscay during August-September 2018. The species was recorded at 13 consecutive sampling sites from Comillas (Spain, Site 1) to Biarritz (France, Site 13) (Fig. 2A-D, Fig. 3, Fig. 4A). Ostreopsis spp. cells were found in sites characterized by rocky substrates and the presence of macroalgae, even in wave-exposed conditions (Biarritz). No Ostreopsis spp. cells were found north of Biarritz (from Site 14 to Site 20) in coastal zones corresponding to sandy ecosystems. In the middle (from Site 21 to Site 26) and in the north (From Site 28 to Site 40) of the Bay of Biscay, despite the presence of rocky substrates and extensive macroalgae coverage, no Ostreopsis cells were observed under light microscopy. In stations where Ostreopsis cells were observed, the maximum mean cell abundance was found in Hondarribia (Spain, Site 8) with $291073 \pm 37712$ cells/gFW (mean \pm standard deviation) while the lowest abundance was found in Biarritz with $9 \pm 16$ cells/gFW.

Ostreopsis spp. cell observations were coincident with sea temperatures ranging from $21.1^{\circ} \mathrm{C}$ to $25.9^{\circ} \mathrm{C}$ and salinities ranging from 28.4 to 34.8 . Water salinities recorded in Sites 16 and 17 were 
extremely low (respectively 6.8 and 3.0 ) as these samples were collected in estuary habitats in order to verify the absence of cells in low salinity conditions.

In terms of biological substrates, taxonomic identification of macroalgae was successful for 81 of the 111 samples collected. The presence of epiphytic Ostreopsis spp. cells was confirmed on nine different genera of macroalgae. High levels of benthic abundances were recorded on Gelidium spp., Centroceras spp., Halopteris spp., Cystoseira tamariscifolia and Corallina spp. (> 15000 cell/gFW). However, the relationship between cell abundances and type of macroalga could not be assessed since the macroalgae collected differed among sites.

\section{Isolation of strains and species identification}

Monoclonal cultures were obtained from sites where living Ostreopsis spp. cells could be observed in freshly collected benthic samples. In total, 67 monoclonal Ostreopsis spp. strains were established from seven Spanish sites (Fig. 2A-D). Of these, 64 sequences from the amplified products were unambiguously assigned to $O$. cf. siamensis (Table 2), exhibiting a percent identity greater than $97 \%$ with the highest similar sequence following Nucleotide Blast. The three remaining sequences were either not long enough or DNA sequencing failed to provide usable data for identification. Sequence lengths varied from 245 bp to $435 \mathrm{bp}$. Fifty-one new strain sequences were most similar to the sequence KT868527.1 (Australian strain CAWD203), four to the sequence MH478526.1 (Portuguese strain IPMA01) and eight to the sequence MH790464.1 (Spanish strain IRTA-SMM-16-84) (Table 2).

Environmental DNA (eDNA) analysis

eDNA samples were collected from both nylon screens (spatial survey in 40 sites) and plastic polymer substrates (temporal survey in 2 sites during 13 months) of the Bay of Biscay (Fig.1). Of the 112 and 118 eDNA samples collected on nylon screen and plastic substrates, respectively, 45 and 5 
were positive for $O$. cf. siamensis. All samples were negative for $O$. cf. ovata. All positive qPCR products sequenced were associated with the sequence MH478557.1 (Portuguese strain 1096-08), with a percent identity that was always higher than $96 \%$ for nylon screen samples and higher than $92 \%$ for plastic polymer substrate samples and with an e-value always lower than $1 \times 10^{-10}$ (Supplementary Material 1). Data from qPCR products positive for $O$. cf. siamensis and sequencing were used for ecological analyses.

The cell-based standard curves covered linear detection over five orders of magnitude, with a mean qPCR efficiency of $82.5 \%$ (slope $=-3.828$ ) for 0 . cf. siamensis (Supplementary Material 2). The slope $(-3.828)$ and intercept $(+20.40)$ of the mean standard curve were used to estimate $O$. cf. siamensis eDNA concentrations in field samples from cycle threshold $(\mathrm{Ct})$ values derived from the fluorescence intensity of the qPCR assays. No amplification was observed in the negative control templates (DNAse-free water) whereas all the positive control templates were successfully amplified and were used to define the primer melting temperature associated with 0 . cf. siamensis (Supplementary Material 3). The Ct values obtained ranged from 16.8 to 39.8, allowing the detection of amount of DNA inferior to $0.001 \mathrm{ng} / \mathrm{\mu L}$

Given the possible sources of bias in Ostreospsis spp. eDNA quantification by qPCR that have not been completely addressed in this study (sampling bias, DNA extraction yield, PCR inhibition and qPCR efficiency), qPCR data were interpreted as a tool to verify the presence of $O$. cf. siamensis in our samples and, in a semi-quantitative way, to suggest a potential distribution pattern of the species in the study area. Ostreopsis cf. siamensis eDNA was found, and semi-quantified, in artificial substrate samples collected in 23 of the 40 sampling sites. Comillas (Spain, Site 1) and Plouguerneau (France, Site 39) represented, respectively, the westernmost and northernmost sites where $O$. cf. siamensis was detected across the study area (Fig. 4B). Ostreopsis cf. siamensis eDNA was detected at all sites (1-13) where cells had been observed under light microscopy (Fig. 4A, 4B); the presence of the species was confirmed in the three replicates collected for genetic analysis at almost all of these sites (Fig. 4B).

This article is protected by copyright. All rights reserved. 
The highest $O$. cf. siamensis eDNA concentrations were estimated to occur at Sites 3, 5, 6 and 7 (Fig. $4 C)$.

Whereas no 0 . cf. siamensis cells were observed by light microscopy in any of the sites located at a higher latitude than Site 13 (Fig. 4A), its presence was confirmed by qPCR analyses in 1-2 replicates of the samples collected in the middle of the bay (Sites 14-23, with the exception of Sites 17 and 20). In these samples, low eDNA concentrations were estimated, with the exception of Site 23 (Les Sables d'Olonne) where $O$. cf. siamensis eDNA concentrations were close to those measured in the south of the bay (Fig. 4C). Some positive findings were observed up to the northernmost stations of the study area (Sites 35-39, with the exception of Sites 38 and 40 ) but only in one sample replicate and at very low concentrations $\left(<10^{-2} \mathrm{ng} / \mu \mathrm{l}\right)$. No correlation was observed between $O$. cf. siamensis cell abundance and mean eDNA estimation (Spearman test, $r s=0.518, p$-value $>0.05$ ), probably due to methodological bias. However, when $O$. cf. siamensis eDNA was detected, a positive correlation was found between the number of positive replicates per site and mean eDNA estimation (Spearman, $r s=$ $0.653, p$-value $<<0.01)$.

Ostreopsis cf. siamensis eDNA was detected on different plastic substrates collected at the temporal monitoring sites of La Tremblade and Brest, confirming the presence of the species in these areas. The presence of $O$. cf. siamensis was detected in two samples collected in late spring (AprilJune) 2018 at both sites, and in one sample collected at the end of September - beginning of October 2018 in La Tremblade (Fig. 5). No relationship between the type of polymer and O. cf. siamensis eDNA was found as the species was detected at least once on every polymer used during the monitoring period. At the time of the spatial survey (August-beginning of September 2018), O. cf. siamensis was not detected in La Tremblade or Brest.

This article is protected by copyright. All rights reserved. 


\section{Connectivity analysis}

The connectivity among sampled areas (Fig. 1) was analyzed using a Lagrangian framework (i.e. particle tracking), which is classically used to study subpopulations and/or marine protected area connectivity (Mitarai et al., 2009; Pujolar et al., 2013). Within the transport time considered (90 days), none of the areas appeared to be connected to all the others (Fig. 6, Supplementary Material 4). Particles released from Area A could only reach Areas B, C, D and E, Area E being the farthest away. Equally, particles that could reach Area $\mathrm{N}$ must have been released from Area $\mathrm{K}$ or north of this area (Fig. 6). Nonetheless, particle movement patterns were generally fast enough to permit at least five successive areas in both directions to be connected at a seasonal scale. The large numbers of connections between areas from $\mathrm{B}$ to $\mathrm{H}$ along the south and west of the region are due to the presence of regular cyclonic and anticyclonic eddies. Because of this circulation, particles released in these areas remain in the surface mixed layer where the effects of mesoscale and sub-mesoscale processes on the distribution patterns of numerical particles are considerable. Connection times between Area $\mathrm{E}$ to Areas $\mathrm{D}$ and $\mathrm{F}$ in the southeast Bay of Biscay are faster (between 3 and 5 days) than those recorded at other stations due to the continental slope current. This current increases the mixing activity of the particles by generating high turbulent flows. From Areas $\mathrm{F}$ to $\mathrm{H}$, even if a northward connection was observed to the closest station, the main direction of connectivity is southward, and particles can reach Area B. A break in the connectivity time scale is observed around the stations I, J or K for particles going southward and reaching southern areas. The mean TR (transit time) showed that particles needed fewer than 13 days in 2011 and 8 days in 2013 to move from Station $\mathrm{H}$ to Station I but needed more than 85 days in both years to travel from $\mathrm{H}$ to $\mathrm{J}$. The least well-connected cluster was observed from Areas $L$ to N. Finally, estimated connectivity from Areas I, J and $K$ was also very variable between the two simulated years. For example, Area I was connected mainly with southward areas in 2011 whereas 
in 2013, some particles reached Areas K and L. Overall advection also appeared to be stronger in 2013 than in 2011.

\section{Discussion}

Ostreopsis $c f$. siamensis eDNA analysis

Environmental DNA refers to the intracellular (originating from living organisms) and extracellular (resulting from the organism's death) DNA that can be extracted from environmental samples without the need for prior isolation of the targeted organism (Taberlet et al., 2012). Over the last decade eDNA analyses have proved their value to ecological and biodiversity studies (Taberlet et al., 2012; Thomsen and Willerslev, 2015; Lacoursière-Roussel and Deiner, 2019). For instance, the use of eDNA to demonstrate the presence of a target species in an ecosystem is now used more and more, especially for monitoring species and detecting rare species (Jerde et al., 2011; Bohmann et al., 2014; Mächler et al., 2014). The greater accuracy of eDNA detection compared to classical identification surveys saves time, in addition to collecting relevant new information concerning ecological communities and species distribution. In this study, standard benthic macroalgae sampling allowed the identification of sites where $O$. cf. siamensis is developing in large enough concentrations permitting classical observations by light microscopy. Dinoflagellate cells were observed in the southeastern part of the bay, between Comillas (Spain) and Biarritz (France). These observations corroborate the previous reports of $O$. cf. siamensis in the Bay of Biscay (Laza-Martinez et al., 2011; David et al., 2013; Seoane and Siano, 2018). In these studies, the western and northern limits of Ostreopsis cell development have been established as, respectively, Santander (Cantabria) and SaintJean-de-Luz (French Basque Country), while in our study some cells were observed over a slightly larger spatial range (from Comillas (Site 1) to Biarritz (Site 13)). Nevertheless, the detection of $O$. cf. siamensis eDNA by qPCR revealed a wider distribution area of this species in the Bay of Biscay, demonstrating the complementarity of eDNA analyses with classical monitoring surveys. qPCR analysis followed by 
species identification through PCR product sequencing allowed the unambiguous attribution of eDNA qPCR products to $O$. cf. siamensis. Although no cells were observed further north than Biarritz (Site 13), qPCR analyses confirmed the presence of $O$. cf. siamensis eDNA across the whole of the Bay of Biscay and even further to the north, in Plouguerneau (Site 39), in the English Channel.

In this first attempt to describe $O$. cf. siamensis distribution across the Bay of Biscay using eDNA, it was important to evaluate issues associated with the use of this molecular tool. The transport and persistence of extracellular eDNA in marine waters and aquatic environments have been identified as potential sources of false negative and/or positive detection of target organisms (Goldberg et al., 2018), i.e. eDNA could be transported and detected in the sampled area but not the original organism to which the DNA belongs. The majority of studies related to eDNA transport in aquatic environments have been carried out in rivers, where stream flow is mostly unidirectional. These studies have demonstrated that the eDNA of organisms might be retrieved relatively far from the original organism that was its source (Deiner and Altermatt, 2014; Shogren et al., 2017). In the marine environment, where currents are multidirectional and water transport is variable across seasons and years, the study of eDNA transport is much more complicated and has been barely addressed so far. Using Lagrangian particle tracking, Andruszkiewicz et al. (2019) estimated that eDNA could be detected relatively far away from the original source (within $40 \mathrm{~km}$ northward approximately 4 days after shedding). Conversely, Jeunen et al. (2019) showed that eDNA dispersal can be limited within strongly connected marine coastal habitats, demonstrating that the study of eDNA transport is dependent on the specific water circulation of the studied area. The issue of eDNA persistence in marine waters is also still debated. The decay rate of eDNA seems to be influenced by both biotic and abiotic factors, including temperature, $\mathrm{pH}, \mathrm{UV}$ and the microbial community in lotic (Barnes et al., 2014; Strickler et al., 2015; Lance et al., 2017; Seymour et al., 2018) and marine ecosystems (Sassoubre et al., 2016; Andruszkiewicz et al., 2017). In marine systems, Collins et al. (2018) estimated macroorganism (fish and crab) eDNA to be detected for up to $48 \mathrm{~h}$. As for microorganisms and planktonic species, studies conducted on bacterial eDNA (Salmonella spp. and Legionella spp.) also observed a faster rate of 
degradation associated with warmer temperatures, resulting in the complete degradation of eDNA within a few days (Palmer et al., 1993; Dupray et al., 1997).

Lagrangian-based particle transport simulations in the Bay of Biscay showed that the minimum estimated particle-transport time between two relatively close areas in the southern part of the bay $(<60 \mathrm{~km}$ ) was 2-5 days (i.e. between Areas $D$ and $E$ in 2011 and 2013). This indicates that for relatively close areas in the south of the bay, estimated particle-transport time is expected to be very similar to the estimated eDNA persistence time, suggesting that positive detection of $O$. cf. siamensis eDNA in this area could correspond to free cells or to advected extracellular DNA produced from the large population of fixed cells. Conversely, estimated particle-transport time across areas located in the north of the Bay and in the English Channel was always greater than five days (between 20 and 80 days). This time, being longer than eDNA persistence estimates in the marine environment, suggests that even in the northern part of the bay, 0 . cf. siamensis eDNA detections could not be related to advected extracellular DNA but only to the presence of living cells, suggesting that this species is part of the microflora of the Bay of Biscay.

\section{Geographical and niche ranges}

Our study of Ostreopsis spp. distribution at a regional level in the NE Atlantic contributed to the analysis of species distribution partitioning within the genus. Among all the eDNA samples collected and analyzed, O. cf. ovata was not detected. This confirms the hypothesis of David et al. (2013) stating that the distribution of $O$. cf. ovata in the NE Atlantic is limited to south of the Iberian Peninsula (Portugal). In contrast, $O$. cf. siamensis seems to occur infrequently in the Mediterranean Sea, where O. cf. ovata is known to be very abundant (Penna et al., 2010, 2012; Mangialajo et al., 2011; Accoroni and Totti, 2016). This niche partitioning could be explained by the ability of $O$. cf. siamensis to be more resistant to cooler temperatures, lower salinities and/or tidal cycles than $O$. cf. ovata, as David et al. (2013) and Santos et al. (2019) observed O. cf. siamensis at higher latitudes than $O$. cf. ovata in the West of the Iberian Peninsula. In temperate waters both sea temperature and, to a lesser extent, 
salinity are known to be factors affecting the growth of $O$. cf. ovata (Pistocchi et al., 2011; Pezzolesi et al., 2012; Scalco et al., 2012; Accoroni and Totti, 2016; Carnicer et al., 2016). Thus, being less adapted to environmental conditions of the Bay of Biscay than O. cf. siamensis, O. cf. ovata would not be able to develop at higher western latitudes despite its potential northward advection.

The environmental survey performed in this study made possible to identify the geographical range of $O$. cf. siamensis in the Bay of Biscay, a concept related to the ecological niche theory (Peterson, 2011). Species' geographic range is considered as the basic unit of biogeography and represents the area where a species is found (Brown et al., 1996). This range corresponds to the realized niche in the niche concept developed by Hutchinson (1957), where species are found within a space where environmental conditions are favoring their development (Holt, 2003; Sexton et al., 2009). However, dispersal by water circulation can promote the colonization of new ecosystems by microorganisms. Indeed, it is believed the apparent lack of dispersal barriers would confer marine planktonic microorganisms a ubiquitous distribution, especially in species forming resting stages with high dispersal potential. Local environmental constraints and random selection processes would then shape the community structure (Baas Becking, 1934; Fenchel and Finlay, 2004; de Wit and Bouvier, 2006). The distribution of high potential dispersal species can then be explained by the "source-sink" dynamics theory (Pulliam, 1988, 2000), deriving from Hutchinson's niche theory, which suggests that populations issued from a suitable habitat (source) can feed environmentally non-suitable habitats (sinks). Hence, in a scenario where dispersal is high enough, the geographic range of a species can extend beyond its niche range (Hargreaves et al., 2014), which is considered as the zone where environmental factors favor species development. A well-established population of $O$. cf. siamensis has already been documented along the Cantabrian Sea coasts (Laza-Martinez et al., 2011). Along the Atlantic coasts of the Iberian Peninsula, David et al. (2012) linked the presence of $O$. cf. siamensis with sea surface temperature. This was confirmed by Santos et al. (2019), who observed higher Ostreopsis spp. cell abundances following periods of positive sea surface temperature anomalies and low sea state in Lagos Bay (Portugal). In this study, optimal temperature conditions for the occurrence of local 
O. cf. siamensis blooms were found between Santander (Site 2) and Saint-Jean-de-Luz (Site 12). We consider that, so far, this area represents the niche range of the species in the Bay of Biscay, i.e. the optimal zone for its development where the species can bloom. Comillas (Site 1) and Biarritz (Site 13), where cells were observed albeit in very low abundances, represent the edges of this niche range. This limit could potentially extend westward as no site was sampled after Comillas. Following water circulation, the northward dispersion of southern-based populations enables the colonization of the northern areas of the bay, extending the geographical range of $O$. cf. siamensis at least to the north of the Bay of Biscay (Brittany) and the English Channel.

Based on Lagrangian integration, different approaches have been used in the literature to quantify the connectivity of different marine areas (Mitarai et al., 2009; Rossi et al., 2014; Jönsson and Watson, 2016; Costa et al., 2017). The mean and median values of transit time for all particles traveling from one station to another has been applied in this study following the proposal by Costa et al. (2017) of calculating "betweenness", which is the shortest paths between different sites within variable ocean dynamics. Due to its oceanographic characteristics, connectivity between sites located along the coasts of the Bay of Biscay are mainly driven by tidal forcing, wind regimes and oceanic topography, such as continental slopes (Charria et al., 2013). In spring and summer, the period set as the time of particle release in our simulations, the prevailing wind regime generates currents that flow south and westsouthwest, increasing particle travel time towards northern areas. The presence of weak residual currents and vortices with low dispersion rates ensures connectivity between the areas in the south of the bay. These observed seasonal patterns are also strongly dependent on weather variability (Charria et al., 2017). Langrangian particle-tracking simulations demonstrated that, due to its specific ocean dynamics, some key areas were responsible for maintaining continuous dispersal connectivity along the coasts of the Bay of Biscay. Area D, located in the south of the Bay, represents the area where the main $O$. cf. siamensis source population is established and from where cells are dispersed towards northern sites. Area $\mathrm{H}$, located in the middle of the bay, links the southern and northern areas while Area $\mathrm{K}$, located in the north of the bay, is the only area connecting both the English Channel and the 
Bay of Biscay. Hence, dispersal of $O$. cf. siamensis towards the northernmost areas can only be assured if $O$. cf. siamensis cells rest in intermediate "shelter" areas of the bay (Areas $\mathrm{H}$ and $\mathrm{K}$ ) before eventually being dispersed northward. Northern coasts of Brittany along the English Channel (Site 39) and the $48^{\text {th }}$ parallel were identified as the northernmost area where $O$. cf. siamensis could be detected. However, the application of water circulation models connecting the Bay of Biscay, the English Channel and the Celtic Sea could reveal even higher dispersion in the NE Atlantic.

eDNA analysis of the temporal survey data also confirmed the presence of $O$. cf. siamensis in La Tremblade (near Site 20) and in Brest (near Sites 36 and 38) and helped define the time window for the presence of this species in these areas. The ability of marine microorganisms to adhere to, and develop on plastic and synthetic surfaces has been extensively described and represents a potential dispersion vector for microbial communities colonizing drifting plastic substrates (Zettler et al., 2013; Reisser et al., 2014; Oberbeckmann et al., 2015). Plastic colonization has also been observed for dinoflagellates (Masó et al., 2003, 2016; Casabianca et al., 2019, 2020) and has been used for monitoring through artificial substrate sampling methods (Tester et al., 2014; Jauzein et al., 2016; Parsons et al., 2017). The temporal survey carried out on plastic substrates was used in this study to describe the temporal dynamic of $O$. cf. siamensis. Although $O$. cf. siamensis eDNA was found between April and June both in Brest and La Tremblade, and also at the end of September in La Tremblade, the species was not found on artificial substrates at neighbor sites sampled during the period of the spatial sampling survey (August-September). This inconsistency could be probably explained by a spatial variability of Ostreopsis development dynamics in the zones of Brest and Le Tremblade since monitored sites during the spatial and temporal survey were not coincident. However, positive samples found during the temporal surveys suggest a favorable window of development larger than expected prior to the sampling campaign. Coupling temporal and spatial analyses, we can therefore infer that $O$. cf. siamensis can be present, in high enough abundance to be detected using eDNA analyses, in the Bay of Biscay from spring (April-June) to the end of summer (August-September). However, more specific monitoring is needed to assess more precisely the phenology of the species in 
the areas of Brest and Le Tremblade and, for this purpose, both artificial substrates and plastic polymer seem to be adequate tools.

\section{Potential effect of global changes on Ostreopsis cf. siamensis expansion}

Environmental conditions, and especially the water temperature, in the north of the Bay of Biscay are not optimal for $O$. cf. siamensis development. However, global ocean warming induced by climate change may foster $\boldsymbol{O}$. cf. siamensis expansion in new areas where habitat characteristics are suitable for the development of the species (Tester et al., 2020). Yet, if both earth and ocean climates are warming at a global scale since the last century and are related to the large increase in anthropogenic gas emissions (Levitus, 2001; Pierce et al., 2006; Alexander et al., 2018), not all oceans are warming at the same rate. Since 1950 a general increase in North Atlantic Ocean sea surface temperatures (SST) have been observed (Levitus, 2000; Saba et al., 2016; Cheng et al., 2017) simultaneously with multidecadal oscillations corresponding to successive cycles of warming and cooling periods (Polyakov et al., 2005). As part of the North Atlantic, the Bay of Biscay has been affected by both global warming and multidecadal oscillations (deCastro et al., 2009; Costoya et al., 2016). A non-homogenous long-term increasing trend of both surface and intermediate water temperatures of the bay was demonstrated, with the south-eastern area exhibiting both stronger increase in SST and seasonality than the northern area (Koutsikopoulos et al., 1998; Planque et al., 2003; González-Pola, 2005).

Due to the major role played by sea temperature in phytoplankton species ecology (Eppley, 1972; Wells et al., 2015), ocean warming is expected to affect microalgae distribution and phenology (Fu et al., 2012; McLeod et al., 2012; Paerl and Paul, 2012), including benthic species (Tester et al., 2020). Eco-evolutionary models of thermal adaptation mechanisms in phytoplankton species suggest a poleward shift in their thermal niche (Thomas et al., 2012) and simulation models forecast the expansion of potentially toxic species towards higher latitudes (Gobler et al., 2017). Selected species of the genus Ostreopsis spp. are likely to expand beyond their traditional pantropical geographical 
range, colonizing temperate areas at higher latitudes (Tester et al., 2020). Many laboratory studies have suggested that relatively high temperatures were more suitable for optimal Ostreopsis growth, although the thermal niche seems to be species and strain dependent (Granéli et al., 2011; Scalco et al., 2012; Tanimoto et al., 2013; Tawong et al., 2015; Carnicer et al., 2016). However, very little is known about the thermal niche of $O$. cf. siamensis populations in the Bay of Biscay, except the aforementioned observations by David et al. (2012) who hypothesized that the presence of the species was linked with the presence of relative warm waters $\left(19.5^{\circ} \mathrm{C}\right)$ for at least three consecutive months. In our study, $O$. cf. siamensis cells were observed in the southern part of the Bay at temperatures that were always above $21^{\circ} \mathrm{C}$. However, the occurrence of the species has been reported in this study in the cooler northern part of the Bay. Following the global long-term trend of warming waters worldwide, and specifically in the north-easternAtlantic, future expansion of $O$. cf. siamensis distribution from the south-eastern area to the warming northern parts of the Bay of Biscay could be expected. However, the species' physiological adaptations towards evolving sea temperatures will certainly play a role in this expansion, as shown for other HABs species (Flores-Moya et al., 2012). This adaptive process has been poorly studied in $O$. cf. siamensis and predictive models applying such data to achieve a conclusive forecast of the potential expansion of this species are needed.

In order to monitor $O$. cf. siamensis expansion towards higher latitudes, an environmental managing strategy should be undertaken. The inter-site connectivity revealed by our Lagrangian particle-tracking simulations in the Bay of Biscay showed that the areas $\mathrm{D}, \mathrm{H}$ and $\mathrm{K}$ are crucial for the maintenance of a continuous connection between the southern and northern parts of the bay. We propose that these three areas, corresponding to the zones of San Sebastian/Hondarribia/Hendaye (Sites 7, 8, 9; Area D), Les Sables d'Olonne (Site 23; Area H), and Concarneau (Site 33; Area K), should be identified as sentinel areas for future studies conducted on the potential expansion of $O$. cf. siamensis. These areas will be used to establish the recrudescence of bloom phenomena (Area D) as well as the occurrence of potential new blooming areas $(\mathrm{H}$ and $\mathrm{K})$. The use of a specific seasonal monitoring program should be developed with tools adapted to detection of the species. Both eDNA 
samplers (artificial substrate/plastic sampler substrates) and microscopic analysis could be employed, and the identification of high abundances of living cells in microscopical samples instead of eDNA could be used as a proxy of potential species development.

\section{Conclusions}

The effect of sea temperature warming on the expansion of HAB phenomena is a global threat. This study contributes to the assessment of this cause-effect link, using a study area of the northeastern Atlantic, the Bay of Biscay, sensitive to global warming, and a harmful benthic dinoflagellate, O. cf. siamensis, whose distribution is expected to be affected by global water warming. Our innovative eDNA sampling strategy (artificial substrates) allowed us to determine that the species is present in the whole bay and even in the English Channel ( $48^{\text {th }}$ parallel). Within this extended geographical range, the niche range, i.e. the zone where environmental conditions are suitable and where the species can bloom, is limited to the south of the Bay. In addition, the temporal eDNA survey suggested the presence of the species to extend from April to September. Our Lagrangian model simulations of particle dispersal did not only help to demonstrate that cells can be transported from the south to the north of the Bay of Biscay, but also revealed that key zones in the middle of the bay formed a staging post to allow this distribution across the bay. We believe that expansion toward the north of the Bay is currently limited by temperature, but the thermal tolerance of $O$. cf. siamensis to lower and higher temperatures is yet to be demonstrated. In order to monitor such an expansion, we propose to establish specific monitoring programs at three different latitudes, corresponding to the three most closely connected areas of the bay (San Sebastian/Hondarribia/Hendaye, Les Sables d'Olonne and Concarneau). This monitoring could be enlarged to northern areas of the English Channel (England, Wales, Ireland), where water circulation could promote species dispersal and colonization.

\section{Experimental procedures}

This article is protected by copyright. All rights reserved. 
Study area

The Bay of Biscay (North-East Atlantic Ocean) extends from the northwestern territories of the Iberian Peninsula (Galicia, Spain), covering the whole Cantabrian Sea, to the northwestern territories of Brittany (Bay of Brest, France). A total of 40 sites, along both the French and Spanish coasts of the Bay, were sampled from August to September 2018 (Table 1). The sampling temporal window and track direction (northward in France and eastward in Spain) were chosen in order to sample waters during the warmest period of the year. French sites and Spanish sites were sampled in parallel. Spanish sites were sampled in one week starting from Hondarribia to Comillas (Fig. 1); whereas French sites were sampled over four weeks from Hendaye to Roscoff (Fig. 1), using a camping van as a mobile laboratory for rapid sample processing.

Prior to sampling, the benthic facies and habitats of the studied area were carefully examined using satellite images to select sites maximizing the chances of observation and collection of Ostreopsis spp. cells. The environmental features identified as potential sites for the development of Ostreopsis spp. were sheltered habitats providing low exposure to wave action and the presence of rocky substrates that support macroalgal settlement. Several sites that did not strictly meet these criteria (beach sites located in French Aquitaine) were also sampled in order to maintain distances of less than $100 \mathrm{~km}$ between the sampling sites. To ensure the consistency of inter-site sample comparisons, and because little is known about Ostreopsis spp. resistance to air exposure at low tide, samples were collected in the lower intertidal zone (sub-mesolittoral zone) at low tide. The sub-mesolittoral zone is generally ( $80 \%$ of the time) immersed, even during low tides. In northern Atlantic waters, this zone is characterized by the presence of distinctive species of macroalgae, such as Fucus serratus Linnaeus or Ascophyllum nodosum Le Jolis in colder waters and Gelidium corneum Lamouroux or Halopteris scoparia Sauvageau in warmer waters. These seaweeds were used as landmarks of the lower intertidal zone at low tides during sampling.

Field sampling of epiphytic microalgal cells and eDNA

This article is protected by copyright. All rights reserved. 
Three macroalgal samples, corresponding to the most abundant species at each site, were collected with surrounding water at a depth of about 0.1-0.5 m, using $250 \mathrm{ml}$ plastic flasks. After shaking the bottle for about 5 minutes, $15 \mathrm{ml}$ of each sample was subsampled and used for observation of living cells, within a few hours of sampling, with a portable light microscope (Bresser ${ }^{\circledR}$ MicroSet, 10x40). Some Ostreopsis cells were isolated from these subsamples to start the establishment of monoclonal cultures. Macroalgae were drained, placed onto a piece of tin foil to measure the fresh weight, and photographed for taxonomic identification. The remaining water was fixed with acid Lugol's solution ( $2 \% \mathrm{vol} / \mathrm{vol})$ and stored in dark glass bottles until the end of the sampling period. In concomitance with macroalgae samples, surface water temperature and salinity were measured with a portable probe (WTW Cond 330i, Germany).

To complete the conventional Ostreopsis spp. sampling of macroalgae, an eDNA approach was adopted, modifying the artificial substrate method developed by Jauzein et al. (2016) to our study and sampling strategy. eDNA was collected using $2 \mathrm{~mm}$ mesh nylon screens, an innovation applied in this study to enhance the possibility of collecting rare DNA traces of Ostreopsis spp. in the environment during substrate immersion. Artificial substrates were placed in the sub-mesolittoral zone of the selected sites at low tide and recovered after two tidal cycles (approximately $24 \mathrm{~h}$ ) (Table 1). At each station three frames, corresponding to three replicates, were anchored to a breeze block. During recovery the frames were carefully removed from the water and the screens were detached and immediately placed into $250 \mathrm{ml}$ plastic flasks filled with seawater that had been collected locally and previously filtered through $0.22 \mu \mathrm{m}$ nitrocellulose filters (Merck Millipore diameter $47 \mathrm{~mm}$, Merck Group, Darmstadt, Germany). The plastic flasks were vigorously shaken in order to detach cells and particles from the screen and the water was then filtered through $3 \mu \mathrm{m}$ polycarbonate filters. Filters were stored in $5 \mathrm{ml}$ cryotubes and flash frozen in liquid nitrogen in a dry shipper container where they were kept until the end of the sampling campaign. At the completion of the campaign, samples were stored at $-80{ }^{\circ} \mathrm{C}$ until molecular biology analysis. In order to avoid cross-station contamination, new screens were deployed at each station and all plastic frames and breeze blocks were decontaminated 
using bleach then rinsed thoroughly with sea water before being re-used. Due to adverse weather conditions during the first sampling day, screens could not be recovered at sites 9 and 10 (Hendaye and Plage Abbadia) and only one sample was recovered at site 8 (Hondarribia).

The eDNA spatial survey was supplemented with a temporal sampling strategy conducted at two reference stations to assess the temporal distribution of Ostreopsis spp. at these sites. A total of 118 eDNA samples collected during a monitoring program aimed at studying the structure and dynamics of microbial communities associated with plastic substrates were analyzed. Four different types of plastic polymers (Nylon [NY], Low Density Polyethylene [LDPE], Polypropylene [PP] and Polyethylene Terephtalate [PET]) were fixed into cages placed in the tidal zone of two sampling sites located in the Bay of Biscay: La Tremblade (La Floride: $45.80388^{\circ} \mathrm{N} ;-1.16193^{\circ} \mathrm{E}$; near site 20 ) and Brest (Pointe-du-Château: $48.33294^{\circ} \mathrm{N} ;-4.32296^{\circ} \mathrm{E}$; near sites 36 and 38). The plastic samples were collected after 15 days of deployment, from December 2017 to December 2018. Plastic substrates with attached biofilms were collected in $5 \mathrm{ml}$ cryotubes, flash frozen in liquid nitrogen and stored at $-80^{\circ} \mathrm{C}$ until molecular biology analysis.

\section{Ostreopsis spp. cell quantification}

The Lugol-fixed samples of epiphytic cells collected from macroalgae were used to estimate benthic cell abundances of Ostreopsis spp.. One $\mathrm{ml}$ of seawater of each sample was analyzed in a Sedgewick Rafter Chamber using an inverted microscope (Axiovert 40 CFL, 10x40, Zeiss, Oberkochen, Germany), and at least 100 cells have been counted for each sample. Cell abundances were estimated as the number of cells per gram of fresh weight of macroalgae (cells $\mathrm{g} / \mathrm{FW}$ ) in order to relate the abundance of epiphytic cells to macroalgal biomass. Mean values and standard deviations per site were calculated over the three cell abundance estimations.

DNA extraction and amplification from cultures and environmental samples

This article is protected by copyright. All rights reserved. 
A total of 67 Ostreopsis spp. strains isolated from seven different sites during the sampling campaign were maintained in culture ( $\mathrm{K}$ medium, $\left.22{ }^{\circ} \mathrm{C}, 100 \mu \mathrm{E} . \mathrm{m}^{-2} . \mathrm{s}^{-1}\right)$. Cultures were developed to produce biomass for accurate genetic species identification and for the calibration of genetic analysis. For DNA extraction, $10 \mathrm{~mL}$ of each culture was centrifuged $(3000 \mathrm{~g} / 10 \mathrm{~min})$ and DNA was extracted from the cell pellet using the DNeasy ${ }^{\circledR}$ Plant Mini Kit (Qiagen, Hilden, Germany), following the manufacturer's instructions. Extracted genomic DNA was eluted in a final volume of $100 \mu \mathrm{l}$ of DNAse-free water (Millipore, Merck Group, Darmstadt, Germany) and stored at $-20^{\circ} \mathrm{C}$ until molecular analysis.

Total DNA from the environmental sample filters was extracted using the lysis buffer-based NucleoSpin ${ }^{\circledast}$ Plant II DNA extraction kit (Macherey Nagel, Hoerdt, France), following the manufacturer's instructions. Total genomic DNA was eluted in a final volume of $100 \mu$ l of DNA-free water, quantified using the Quant-iT ${ }^{\mathrm{TM}}$ PicoGreen ${ }^{\circledR}$ dsDNA assay kit (Invitrogen ${ }^{\mathrm{TM}}$, Waltham, MA, USA) through a spectrophotometer (BioTek ${ }^{\circledast} \mathrm{FLx} 800$, Winooski, VT, USA) and stored at $-20^{\circ} \mathrm{C}$ until molecular analysis.

DNA from the biofilms that had developed on plastic polymer substrate samples collected during the temporal surveys was extracted with a chemical extraction method using Cetrimonium Bromide (CTAB) / Phenol-Chloroform-Isoamyl Alcohol (PCI). Plastic polymers were cut into small pieces and then incubated and agitated ( $300 \mathrm{rpm}$ ) at $60{ }^{\circ} \mathrm{C}$ for $210 \mathrm{~min}$ in $1200 \mu \mathrm{l}$ of filtered CTAB extraction buffer solution (0.1 M Tris pH=8.0; $1.4 \mathrm{M} \mathrm{NaCl} ; 20 \mathrm{mM}$ EDTA pH=8.0; $2 \mathrm{~g}$ CTAB; 20\% SDS; $20 \mathrm{mg} / \mathrm{ml}$ proteinase $\mathrm{K} ; \beta$ mercapto-ethanol). After incubation, the samples were centrifuged (10 min, $12000 \mathrm{~g}$ ) and Phenol:Chloroform:Isoamyl Alcohol (25:24:1) was added (vol/vol) to the supernatant. Samples were then centrifuged (10 $\mathrm{min}, 12000 \mathrm{~g}$ ) to recover the aqueous phase. DNA precipitation was obtained by adding 0.1 volume of sodium acetate $(3 \mathrm{M} \mathrm{pH}=5.2)$ and 0.6 volume of isopropanol and storing samples overnight at $-20^{\circ} \mathrm{C}$. DNA was recovered by centrifugation $\left(30 \mathrm{~min}, 14000 \mathrm{~g}, 4{ }^{\circ} \mathrm{C}\right.$ ) and washed with $0.5 \mathrm{~mL}$ of $70 \%$ ethanol. After centrifugation $\left(20 \mathrm{~min}, 14000 \mathrm{~g}, 4^{\circ} \mathrm{C}\right.$ ), the DNA was dried and resuspended in $50 \mu \mathrm{l}$ of DNase-free water and stored at $-20^{\circ} \mathrm{C}$ until molecular analysis.

This article is protected by copyright. All rights reserved. 
The amplification of genomic DNA extracted from each of the 67 cultures was performed following the protocol described in Penna et al. (2007). Standard PCR using eukaryotic primers targeting the ITS1-5.8S-ITS2 region of the ribosomal DNA (rDNA) was performed using a peqSTAR ${ }^{\circledR}$ thermocycler (VWR ${ }^{\text {TM }}$ Peqlab, Radnor, PA, USA) as follows: $50 \mu$ of mixture containing $200 \mu \mathrm{M}$ of each dNTP (Promega, Madison, WI, USA), 2 mM of $\mathrm{MgCl}_{2}, 0.5 \mu \mathrm{M}$ of primer ITS1F and ITS4R, $1 x$ GoTaq ${ }^{\circledR}$ Flexi Buffer reaction (Promega), $1.25 \mathrm{U}$ of GoTaq ${ }^{\circledR}$ Polymerase (Promega) and $5 \mu$ l of template DNA. Thermal cycling conditions comprised 4 min at $94{ }^{\circ} \mathrm{C}$ for denaturation, followed by 30 cycles of hybridization $\left(94{ }^{\circ} \mathrm{C}\right.$ for $1 \mathrm{~min}, 50{ }^{\circ} \mathrm{C}$ for $2 \mathrm{~min}, 72{ }^{\circ} \mathrm{C}$ for $3 \mathrm{~min}$ ), ending with $72{ }^{\circ} \mathrm{C}$ for $7 \mathrm{~min}$ for final elongation. Amplification products were purified using NucleoSpin ${ }^{\circledR}$ Gel and PCR Clean-up kit (Macherey Nagel, Hoerdt, France) following the manufacturer's instruction. Amplified products were purified (QIAquick PCR Purification Kit, Qiagen) and sent to GATC Biotech (www.eurofinsgenomics.eu/en/custom-dnasequencing/gatc-services) for Sanger sequencing. After quality control, all sequences were analyzed on the National Center for Biotechnology Information website (https://www.ncbi.nlm.nih.gov/) using the tool Nucleotide Blast. For species identification sequences were edited using BioEdit v7.2.5 software (Hall, 1999) and multiple sequence alignment was achieved using the ClustalW program (Thompson et al., 1994) with reference sequences obtained from the BLAST database (Altschul et al., 1990) in GenBank and following recent phylogenetic studies of the genus Ostreopsis (Santos et al., 2019).

Real time PCR of eDNA from environmental samples and plastic polymer substrates

The real-time PCR (qPCR) protocol described in Penna et al. (2007) was used to determine the presence of Ostreopsis spp. DNA in eDNA samples collected in the sampling campaign and the temporal surveys. Three sets of species-specific ITS-5.8 rDNA region primers were used to target Ostreopsis spp., 0 . cf. siamensis and $O$. cf. ovata. qPCR was conducted using the Platinum ${ }^{\circledast}$ SYBR $^{\circledast}$ Green qPCR SuperMixUDG (Invitrogen, Carlsbad, California, USA) and performed on a Stratagene Mx3000P (Agilent 
Technologies, Santa-Clara, California, USA) thermocycler in a final volume of $25 \mu \mathrm{l}$. The reaction mixture was composed of $20 \mu \mathrm{M}$ of each primer, $25 \mu \mathrm{M}$ of $\mathrm{MgCl}_{2}, 12.5 \mu \mathrm{l}$ of SybrGreen Mastermix solution and $2 \mu \mathrm{l}$ of DNA template. The qPCR assays were performed using 96-well plates containing genomic 0 . cf. siamensis DNA dilutions (standard curve), eDNA extracts and both negative (DNAsefree water) and positive (O. cf. siamensis and $O$. cf. ovata cultures) controls. All extracts were run in triplicate. Thermal cycling conditions consisted of $10 \mathrm{~min}$ at $95{ }^{\circ} \mathrm{C}$ for the initial denaturation step, followed by 40 cycles of hybridization $\left(95^{\circ} \mathrm{C}\right.$ for $15 \mathrm{~s}, 60^{\circ} \mathrm{C}$ for $15 \mathrm{~s}, 72{ }^{\circ} \mathrm{C}$ for $15 \mathrm{~s}$ ) and ended with a final cycle of $95{ }^{\circ} \mathrm{C}$ for $1 \mathrm{~min}, 60{ }^{\circ} \mathrm{C}$ for $30 \mathrm{~s}$ and $95{ }^{\circ} \mathrm{C}$ for $30 \mathrm{~s}$. Acquisition of the qPCR data and subsequent analysis were carried out using StepOne Software ver. 2.3 (Applied Biosystem, Carlsbad, California, USA). Standard curves were constructed for eDNA relative quantification using a 5-point tenfold dilution series $\left(5.0 \mathrm{ng} / \mu \mathrm{l}\right.$ to $\left.5.0 \times 10^{-4} \mathrm{ng} / \mu \mathrm{l}\right)$ using DNA extracted from a culture of $O$. cf. siamensis Os-3E (GenBank accession number: MT952070) established from cells isolated in the Cantabrian Sea during a previous field study. The threshold cycle (Ct) for each sample reaction was determined. Initial concentrations of Ostreopsis spp. DNA in environmental samples were estimated by interpolating each $\mathrm{Ct}$ value from samples using the slope of the standard curve and relative eDNA concentrations of $O$. cf. siamensis were calculated from standard curve analysis. Averaged values from the three replicates were used for ecological analysis. Relations between the mean eDNA concentration estimation and both benthic cell abundance and number of positive replicates per site were assessed using the non-parametric Spearman correlation test. Analyses were conducted in RStudio (R Core Team, 2019).

In order to verify the taxonomy of the amplification products, qPCR samples exhibiting a positive signal observed at the corresponding primer melting temperature of $O$. cf. siamensis control samples $\left(79.8^{\circ} \mathrm{C}\right)$ were sent for Sanger sequencing (Eurofins Genomics $\left.{ }^{\odot}\right)$. The eDNA amplification products from artificial substrates samples were identified to species level using reverse primers only (Ostreopsis R in Penna et al. (2007)), which amplifies the most discriminating part of the ITS1-5.8SrDNA at the species level. Samples of the eDNA amplification products from the plastic polymer 
substrates were identified to species level using both forward and reverse primers (Siamensis $\mathrm{F}$ and Ostreopsis R in Penna et al. (2007)) in order to maximize the chances of obtaining the longest sequence possible. After quality control, these sequences were analyzed using the tool Nucleotide Blast (http://www.ncbi.nlm.nih.gov) (Supplementary Material 5).

\section{Advection and connectivity among sampled areas}

In our Lagrangian framework, the ocean circulation was generated with the state-of-the-art ocean general circulation model MARS3D (Lazure and Dumas, 2008) and two configurations (C4 and C1) with different resolutions and external forcing were considered, both covering the entire Bay of Biscay. Detailed descriptions of C4 and C1, including validation processes, can be found in Lazure et al. (2009) and in Charria et al. (2017), respectively. Briefly, C4 and C1 have, respectively, 30 and 100 vertical levels in generalized sigma coordinates and their horizontal resolutions are 4 and $1 \mathrm{~km}$. The $\mathrm{C} 4$ simulation covers the period 1958-2014 with ERA40 and ERA40-Interim ECMFW reanalysis (Uppala et al., 2005; Dee et al., 2011). Boundary conditions were provided by ORCA25 (NEMO configuration) and tides by FES2004 (Lyard et al., 2006) with a larger barotropic model. C1 obviously covers a smaller period (20032012), all boundary conditions were derived from the DRAKKAR global configuration ORCA12_L46_MJM88 (Molines et al., 2014) and some sponge layers were used. Tidal data was provided in the same way as those for $\mathrm{C} 4$. No validated configuration was available for the sampling period (2018) since configuration set-up and in situ data processing have not yet been performed for that year. Existing validated simulations from 2010 to 2014 were thus chosen to catch a part of the inter-annual variability and to describe the average patterns of advection along the Bay of Biscay.

Connectivity between the 14 coastal areas (from $\mathrm{A}$ to $\mathrm{N}$ ), including almost all the sites sampled during the campaign (Fig. 1), was assessed using different Lagrangian indices. Particle trajectories were computed with ocean circulations and an offline Lagrangian mass-preserving scheme from Ichthyop software (V3.3, www.ichthyop.org, Lett et al., 2008). Four Lagrangian indices based on the transit time (TR) between two areas were estimated: "mean", "minimum", "median" and "most frequent value" 
(the value that appeared most often). Correlations were calculated between the different Lagrangian indices and the mean TR was retained and used for subsequent analysis because this index exhibited the highest correlation with the other indices (>0.91, see Supplementary Material 6$)$. In addition, mean TR correlations were also performed between the simulated years (2010 to 2014) to analyze the interannual variability over this five-year period. 2011 and 2013 appeared as the two years with the most different connectivity patterns and have been retained for the following analyses (Supplementary Material 4).

In order to cover the entire potential reproductive period (summer), particles were released daily $\left(\simeq 11000\right.$ particles per day at a random initial time of the day, for a total of $1.10^{6}$ particles per area) during a restricted period of ninety days (June-August). Although positive relative cell buoyancy has been observed in nature (pelagic cells of Ostreopsis are mainly observed in surface layers in floating mucilaginous aggregates), it was considered as a first approximation that particles exhibited neutral buoyancy and were transported with water masses after their release in the surface layer from benthic substrates. Assuming that cell survival during water transport might be influenced by seawater temperature, two different particles datasets were used. The first scenario included all numerical trajectories without any biological filter and the second filtered trajectories which had not encountered a cold temperature threshold (fixed at $16^{\circ} \mathrm{C}$ ). Given the dearth of data regarding $O$. cf. siamensis thermal preferendum in temperate areas, this filter of $16{ }^{\circ} \mathrm{C}$ was based on data available for the well-studied $O$. cf. ovata as this species has been reported to form blooms in water temperatures ranging from $17^{\circ} \mathrm{C}$ to $29^{\circ} \mathrm{C}$ (Accoroni and Totti, 2016; Tester et al., 2020). Therefore, $16{ }^{\circ} \mathrm{C}$ was considered to be a reasonable non-optimal temperature for $O$. cf. siamensis.

\section{Acknowledgement}

This work was carried out in the frame the PhD thesis of $K D$, supported by the project CoCliME which is part of ERA4CS, an ERA-NET initiated by JPI Climate, and funded by EPA (IE), ANR (FR), BMBF (DE), UEFISCDI (RO), RCN (NO) and FORMAS (SE), with co-funding by the European Union (Grant 690462). 
The survey in the Spanish Basque Coast was partially funded by the call for research groups from the University of the Basque Country (PPG17/67). The temporal survey on plastic substrates was carried out in the frame of the project Merlin Microplastique financed by Ifremer. We thank Ifremer laboratories of Anglet, La Tremblade and Nantes for their help during the sampling campaign. We are also grateful to Christophe Six for sharing his precious knowledge on macroalgae identification and zonation during the sampling campaign and Julien Quéré, Sophie Schimtt and Jérémy Simonnet for their precious assistance during genetic analyses. French authors are part of GDR PHYCOTOX (https://www.phycotox.fr/), a CNRS/IFREMER network on HAB. We address our sincere gratitude to the reviewers who accepted to review this manuscript and who helped to its improving. All co-authors have no conflict of interest for the material published.

\section{Authors' contribution}

K.D., R.S., C.J. and R.L. designed and planned the sampling campaign. K.D., R.S., C.J., A.L-Z. and S.S. conducted the spatial sampling campaign. C.L. organized the plastic polymer temporal survey and collected the samples. K.D. analyzed all samples. S.H., M.S. and M.P. designed and performed the modeling analyses. K.D., R.S., C.J., D.H-H., S.H., M.S. and M.P. analyzed the results and prepared the figures. K.D. and R.S. wrote the manuscript. All authors reviewed and accepted the final version of the manuscript.

\section{Figures and table legends}

Table 1: Sampling site information and environmental data collected during the sampling campaign.

Table 2: Information of the 64 new isolated, sequenced and genetically identified Ostreopsis cf. siamensis strains.

This article is protected by copyright. All rights reserved. 
Figure 1: Map of the study area and sampling sites along the Bay of Biscay during the 2018 sampling campaign. Black points represent the 40 sites sampled during the campaign. Red frames represent the areas used for connectivity analyses. Orange squares represent the two sites used for plastic polymer temporal sampling.

Figure 2: Micrographs of the same cell of Ostreopsis cf. siamensis in apical view from strain Z1 (Genbank accession number: MT952050) isolated in this study in light microscopy (A) and in epifluorescence microscopy under respectively green and UV-light illumination to highlight chloroplasts (B) or thecal plates (C, Calcofluor white-stained cell). D) Cell collected from macroalgae sample at site 12 (Saint-Jean de Luz Est) under UV-light (Solophenyl Flavine-stained cell). Scale bars= $10 \mu \mathrm{m}$

Figure 3: Abundances of epiphytic Ostreopsis spp. as cells per gram of macroalgae fresh weight (cell/gFW) in each sampling site in relation to water temperature and salinity across the Bay of Biscay.

Figure 4: Spatial distribution of Ostreopsis cf. siamensis in the Bay of Biscay. Abundance of epiphytic cells assessed by light microscopy counting (A). eDNA detection (B) and estimation (C) of $O$. cf. siamensis assessed by qPCR analyses.

Figure 5: Temporal distribution of Ostreopsis cf. siamensis inferred from environmental DNA analyses carried out on plastic polymer substrates collected in 2017 and 2018 in Brest and La Tremblade. Plastic polymer substrates were immersed for two weeks, indicated with number for each year. Positive detection corresponds to the validation of $O$. cf. siamensis sequence from qPCR products. The type of polymer substrate of positive samples is indicated (LDPE = Low Density Polyethylene; PP = Polypropylene; $\mathrm{PET}=$ Polyethylene Terephtalate; NY = Nylon) .

This article is protected by copyright. All rights reserved. 
Figure 6: Summer connectivity from areas D (green), H (light blue) and K (dark blue) in 2011 and 2013. The networks (directed graph) illustrate relationships between stations for each year. In the maps the nodes (circles) are Ostreopsis cf. siamensis areas (from A to N) considered in the analysis and the edges (lines) width are proportional to the mean transit time of particles between pairs of stations.

\section{List of Supplementary Material}

Supplementary Material 1:

- Supplementary table 1: qPCR analysis and sequences identification data of collected samples from artificial substrates

Supplementary Material 2:

- Supplementary figure 1: rt-PCR cell-based standard curves

Supplementary Material 3:

- Supplementary figure 2: Dissociation curves (A) and amplification plots (B) of rt-PCR performed on environmental samples

Supplementary Material 4:

- Supplementary figure 3: Ostreopsis cf. siamensis connectivity matrix showing the "mean transit time" (days) between the releasing (particle deployment) areas (x-axis) and the receiving areas (y-axis) in spring-summer 2011. Model horizontal resolution $=4 \mathrm{~km}$.

- Supplementary figure 4: Ostreopsis cf. siamensis connectivity matrix showing the "mean transit time" (days) between the releasing (particle deployment) areas ( $\mathrm{x}$-axis) and the receiving areas (y-axis) in spring-summer 2011. The data showed are based on simulations that used the temperature limitation of $16^{\circ} \mathrm{C}$. Model horizontal resolution $=4 \mathrm{~km}$.

This article is protected by copyright. All rights reserved. 
- Supplementary figure 5: Ostreopsis cf. siamensis connectivity matrix showing the "mean transit time" (days) between the releasing (particle deployment) areas (x-axis) and the receiving areas (y-axis) in spring-summer 2013. Model horizontal resolution $=4 \mathrm{~km}$.

- Supplementary figure 6: Ostreopsis cf. siamensis connectivity matrix showing the "mean transit time" (days) between the releasing (particle deployment) areas ( $\mathrm{x}$-axis) and the receiving areas (y-axis) in spring-summer 2013. The data showed are based on simulations that used the temperature limitation of $16^{\circ} \mathrm{C}$. Model horizontal resolution $=4 \mathrm{~km}$.

- Supplementary figure 7: Ostreopsis cf. siamensis connectivity matrix showing the "mean transit time" (days) between the releasing areas, in spring-summer from 2010 to 2014 . Model horizontal resolution $=4 \mathrm{~km}$.

- Supplementary figure 8: Ostreopsis cf. siamensis connectivity matrix showing the "mean transit time" (days) between the releasing (particle deployment) areas in spring-summer from 2010 to 2014 . The data showed are based on simulations that used the temperature limitation of $16^{\circ} \mathrm{C}$. Model horizontal resolution $=4 \mathrm{~km}$.

Supplementary Material 5:

- Sequence alignment (FASTA file)

Supplementary Material 6:

- Supplementary table 2: Correlation values between Lagrangian indices

- Supplementary table 3: Correlation values of mean transit time between different years

This article is protected by copyright. All rights reserved. 


\section{References}

Accoroni, S. and Totti, C. (2016) The toxic benthic dinoflagellates of the genus Ostreopsis in temperate areas: a review. Adv Oceanogr Limnol 7: 1-15.

Alexander, M.A., Scott, J.D., Friedland, K.D., Mills, K.E., Nye, J.A., Pershing, A.J., and Thomas, A.C. (2018) Projected sea surface temperatures over the $21^{\text {st }}$ century: Changes in the mean, variability and extremes for large marineecosystem regions of Northern Oceans. Elem Sci Anth 6: 9.

Altschul, S.F., Gish, W., Miller, W., Myers, E.W., and Lipman, D.J. (1990) Basic local alignment search tool. J Mol Biol 215: 403-410.

Amorim, A., Veloso, N., and Penna, A. (2010) First detection of Ostreopsis cf. siamensis in Portuguese coastal waters. Harmful Algae News 42: 6-7.

Anderson, D.M. (2009) Approaches to monitoring, control and management of harmful algal blooms (HABs). Ocean Coast Manag 52: 342-347.

Anderson, D.M., Cembella, A.D., and Hallegraeff, G.M. (2012) Progress in understanding Harmful Algal Blooms: paradigm shifts and new technologies for research, monitoring, and management. Annu Rev Mar Sci 4: 143-176.

Andruszkiewicz, E.A., Koseff, J.R., Fringer, O.B., Ouellette, N.T., Lowe, A.B., Edwards, C.A., and Boehm, A.B. (2019) Modeling environmental DNA transport in the coastal ocean using lagrangian particle tracking. Front Mar Sci 6: 477.

Andruszkiewicz, E.A., Sassoubre, L.M., and Boehm, A.B. (2017) Persistence of marine fish environmental DNA and the influence of sunlight. PLOS ONE 12: e0185043.

Baas Becking, L.G.M. (1934) Geobiologie of inleiding tot de milieukunde. Hague Neth WP Van Stock Zoon Dutch.

Barnes, M.A. and Turner, C.R. (2016) The ecology of environmental DNA and implications for conservation genetics. Conserv Genet 17: 1-17.

This article is protected by copyright. All rights reserved. 
Barnes, M.A., Turner, C.R., Jerde, C.L., Renshaw, M.A., Chadderton, W.L., and Lodge, D.M. (2014) Environmental conditions influence eDNA persistence in aquatic systems. Environ Sci Technol 48: 1819-1827.

Battocchi, C., Totti, C., Vila, M., Masó, M., Capellacci, S., Accoroni, S., et al. (2010) Monitoring toxic microalgae Ostreopsis (dinoflagellate) species in coastal waters of the Mediterranean Sea using molecular PCR-based assay combined with light microscopy. Mar Pollut Bull 60: 10741084.

Berdalet, E., Kudela, R., Urban, E., Enevoldsen, H., Banas, N., Bresnan, E., et al. (2017) GlobalHAB: a new program to promote international research, observations, and modeling of Harmful Algal Blooms in aquatic systems. Oceanography 30: 70-81.

Berdalet, E., Tester, P., Chinain, M., Fraga, S., Lemée, R., Litaker, W., et al. (2017) Harmful Algal Blooms in benthic systems: recent progress and future research. Oceanography 30: 36-45.

Blanfuné, A., Boudouresque, C.F., Grossel, H., and Thibaut, T. (2015) Distribution and abundance of Ostreopsis spp. and associated species (Dinophyceae) in the northwestern Mediterranean: the region and the macroalgal substrate matter. Environ Sci Pollut Res 22: 12332-12346.

Bohmann, K., Evans, A., Gilbert, M.T.P., Carvalho, G.R., Creer, S., Knapp, M., et al. (2014) Environmental DNA for wildlife biology and biodiversity monitoring. Trends Ecol Evol 29: 358-367.

Brown, A.R., Lilley, M., Shutler, J., Lowe, C., Artioli, Y., Torres, R., et al. (2019) Assessing risks and mitigating impacts of harmful algal blooms on mariculture and marine fisheries. Rev Aquac raq.12403.

Brown, J.H., Stevens, G.C., and Kaufman, D.M. (1996) The geographic range: size, shape, boundaries, and internal structure. Annu Rev Ecol Syst 27: 597-623.

Cagide, E., Louzao, M.C., Espiña, B., Vieytes, M.R., Jaen, D., Maman, L., et al. (2009) Production of functionally active palytoxin-like compounds by Mediterranean Ostreopsis cf. siamensis. Cell Physiol Biochem 23: 431-440.

This article is protected by copyright. All rights reserved. 
Carnicer, O., García-Altares, M., Andree, K.B., Tartaglione, L., Dell'Aversano, C., Ciminiello, P., et al. (2016) Ostreopsis cf. ovata from western Mediterranean Sea: physiological responses under different temperature and salinity conditions. Harmful Algae 57: 98-108.

Casabianca, S., Capellacci, S., Giacobbe, M.G., Dell'Aversano, C., Tartaglione, L., Varriale, F., et al. (2019) Plastic-associated harmful microalgal assemblages in marine environment. Environ Pollut 244: 617-626.

Casabianca, S., Capellacci, S., Penna, A., Cangiotti, M., Fattori, A., Corsi, I., et al. (2020) Physical interactions between marine phytoplankton and PET plastics in seawater. Chemosphere 238: 124560.

Casabianca, S., Casabianca, A., Riobó, P., Franco, J.M., Vila, M., and Penna, A. (2013) Quantification of the toxic dinoflagellate Ostreopsis spp. by qPCR Assay in Marine Aerosol. Environ Sci Technol 47: 3788-3795.

Casabianca, S., Perini, F., Casabianca, A., Battocchi, C., Giussani, V., Chiantore, M., and Penna, A. (2014) Monitoring toxic Ostreopsis cf. ovata in recreational waters using a qPCR based assay. Mar Pollut Bull 88: 102-109.

Charria, G., Lazure, P., Le Cann, B., Serpette, A., Reverdin, G., Louazel, S., et al. (2013) Surface layer circulation derived from Lagrangian drifters in the Bay of Biscay. J Mar Syst 109-110: S60-S76.

Charria, G., Theetten, S., Vandermeirsch, F., Yelekçi, Ö., and Audiffren, N. (2017) Interannual evolution of (sub)mesoscale dynamics in the Bay of Biscay. Ocean Sci 13: 777-797.

Cheng, L., Trenberth, K.E., Fasullo, J., Boyer, T., Abraham, J., and Zhu, J. (2017) Improved estimates of ocean heat content from 1960 to 2015. Sci Adv 3: e1601545.

Cheng, Y.S., Zhou, Y., Irvin, C.M., Pierce, R.H., Naar, J., Backer, L.C., et al. (2005) Characterization of marine aerosol for assessment of human exposure to brevetoxins. Environ Health Perspect 113: 638-643.

This article is protected by copyright. All rights reserved. 
Chomérat, N., Bilien, G., Derrien, A., Henry, K., Ung, A., Viallon, J., et al. (2019) Ostreopsis lenticularis Y. Fukuyo (Dinophyceae, Gonyaulacales) from French Polynesia (South Pacific Ocean): A revisit of its morphology, molecular phylogeny and toxicity. Harmful Algae 84: 95-111.

Chomérat, N., Bilien, G., Viallon, J., Hervé, F., Réveillon, D., Henry, K., et al. (2020) Taxonomy and toxicity of a bloom-forming Ostreopsis species (Dinophyceae, Gonyaulacales) in Tahiti island (South Pacific Ocean): one step further towards resolving the identity of $O$. siamensis. Harmful Algae 98: 101888.

Ciminiello, P., Dell'Aversano, C., Dello lacovo, E., Fattorusso, E., Forino, M., Grauso, L., et al. (2012) Isolation and structure elucidation of Ovatoxin-a, the major toxin produced by Ostreopsis ovata. J Am Chem Soc 134: 1869-1875.

Ciminiello, P., Dell'Aversano, C., Fattorusso, E., Forino, M., Magno, G.S., Tartaglione, L., et al. (2006) The Genoa 2005 outbreak. Determination of putative palytoxin in Mediterranean Ostreopsis ovata by a new liquid chromatography tandem mass spectrometry method. Anal Chem 78: 6153-6159.

Ciminiello, P., Dell'Aversano, C., lacovo, E.D., Fattorusso, E., Forino, M., Tartaglione, L., et al. (2014) First finding of Ostreopsis cf. ovata toxins in marine aerosols. Environ Sci Technol 48: 35323540.

Ciminiello, P., Dell'Aversano, C., lacovo, E.D., Fattorusso, E., Forino, M., Tartaglione, L., et al. (2013) Investigation of toxin profile of Mediterranean and Atlantic strains of Ostreopsis cf. siamensis (Dinophyceae) by liquid chromatography-high resolution mass spectrometry. Harmful Algae 23: $19-27$.

Cohu, S., Mangialajo, L., Thibaut, T., Blanfuné, A., Marro, S., and Lemée, R. (2013) Proliferation of the toxic dinoflagellate Ostreopsis cf. ovata in relation to depth, biotic substrate and environmental factors in the North West Mediterranean Sea. Harmful Algae 24: 32-44.

This article is protected by copyright. All rights reserved. 
Coleman, M.A., Feng, M., Roughan, M., Cetina-Heredia, P., and Connell, S.D. (2013) Temperate shelf water dispersal by Australian boundary currents: Implications for population connectivity. Limnol Oceanogr Fluids Environ 3: 295-309.

Collins, R.A., Wangensteen, O.S., O'Gorman, E.J., Mariani, S., Sims, D.W., and Genner, M.J. (2018) Persistence of environmental DNA in marine systems. Commun Biol 1: 185.

Costa, A., Petrenko, A.A., Guizien, K., and Doglioli, A.M. (2017) On the calculation of betweenness centrality in marine connectivity studies using transfer probabilities. PLOS ONE 12: e0189021.

Costoya, X., Fernández-Nóvoa, D., deCastro, M., Santos, F., Lazure, P., and Gómez-Gesteira, M. (2016) Modulation of sea surface temperature warming in the Bay of Biscay by Loire and Gironde Rivers. J Geophys Res Oceans 121: 966-979.

David, H., Ganzedo, U., Laza-Martínez, A., and Orive, E. (2012) Relationships between the presence of Ostreopsis (Dinophyceae) in the Atlantic coast of the Iberian Peninsula and sea-surface temperature. Cryptogam Algol 33: 199-207.

David, H., Laza-Martínez, A., Miguel, I., and Orive, E. (2013) Ostreopsis cf. siamensis and Ostreopsis cf. ovata from the Atlantic Iberian Peninsula: Morphological and phylogenetic characterization. Harmful Algae 30: 44-55.

Davidson, K., Gowen, R.J., Harrison, P.J., Fleming, L.E., Hoagland, P., and Moschonas, G. (2014) Anthropogenic nutrients and harmful algae in coastal waters. J Environ Manage 146: 206-216. de Castro, M., Gómez-Gesteira, M., Alvarez, I., and Gesteira, J.L.G. (2009) Present warming within the context of cooling-warming cycles observed since 1854 in the Bay of Biscay. Cont Shelf Res 29: 1053-1059.

de Wit, R. and Bouvier, T. (2006) "Everything is everywhere, but, the environment selects"; what did Baas Becking and Beijerinck really say? Environ Microbiol 8: 755-758

Dee, D.P., Uppala, S.M., Simmons, A.J., Berrisford, P., Poli, P., Kobayashi, S., et al. (2011) The ERAInterim reanalysis: configuration and performance of the data assimilation system. $Q J R$ Meteorol Soc 137: 553-597.

This article is protected by copyright. All rights reserved. 
Deiner, K. and Altermatt, F. (2014) Transport distance of invertebrate environmental DNA in a natural River. PLOS ONE 9: e88786.

Dupray, E., Caprais, M.P., Derrien, A., and Fach, P. (1997) Salmonella DNA persistence in natural seawaters using PCR analysis. J Appl Microbio/ 82: 507-510.

Durando, P., Ansaldi, F., Oreste, P., Moscatelli, P., Marensi, L., Grillo, C., et al. (2007) Ostreopsis ovata and human health: epidemiological and clinical features of respiratory syndrome outbreaks from a two-year syndromic surveillance, 2005-06, in north-west Italy. Euro Surveill Bull Eur Sur Mal Transm Eur Commun Dis Bull 12: E070607.1.

Eppley, R. (1972) Temperature and phytoplankton growth in the sea. Fish Bull 70: 1063-1085.

Etheridge, S.M. (2010) Paralytic shellfish poisoning: seafood safety and human health perspectives. Toxicon 56: 108-122.

Faust, M.A., Morton, S.L., and Quod, J.P. (1996) Further SEM study of marine dinoflagellates: the genus Ostreopsis (Dinophyceae)1. J Phycol 32: 1053-1065.

Fenchel, T. and Finlay, B.J. (2004) The ubiquity of small species: patterns of local and global diversity. BioScience 54: 777.

Fitzpatrick, E., Caron, D.A., and Schnetzer, A. (2010) Development and environmental application of a genus-specific quantitative PCR approach for Pseudo-nitzschia species. Mar Biol 157: 11611169.

Flores-Moya, A., Rouco, M., García-Sánchez, M.J., García-Balboa, C., González, R., Costas, E., and LópezRodas, V. (2012) Effects of adaptation, chance, and history on the evolution of the toxic dinoflagellate Alexandrium minutum under selection of increased temperature and acidification: evolution of Alexandrium. Ecol Evol 2: 1251-1259.

Fu, F., Tatters, A., and Hutchins, D. (2012) Global change and the future of harmful algal blooms in the ocean. Mar Ecol Prog Ser 470: 207-233.

This article is protected by copyright. All rights reserved. 
Galluzzi, L., Penna, A., Bertozzini, E., Vila, M., Garcés, E., and Magnani, M. (2004) Development of a Real-Time PCR Assay for Rapid Detection and Quantification of Alexandrium minutum (a Dinoflagellate). Appl Environ Microbiol 70: 1199-1206.

Garvetto, A., Nézan, E., Badis, Y., Bilien, G., Arce, P., Bresnan, E., et al. (2018) Novel widespread marine oomycetes parasitising diatoms, including the toxic Genus Pseudo-nitzschia: genetic, morphological, and ecological characterisation. Front Microbiol 9: 2918.

Ginders, M.A., Collier, K.J., Duggan, I.C., and Hamilton, D.P. (2016) Influence of hydrological connectivity on plankton communities in natural and reconstructed side-arms of a large New Zealand river: influence of hydrological connectivity on plankton communities. River Res Appl 32: $1675-1686$.

Glibert, P., Seitzinger, S., Heil, C., Burkholder, J., Parrow, M., Codispoti, L., and Kelly, V. (2005) The role of eutrophication in the global proliferation of Harmful Algal Blooms. Oceanography 18: 198209.

Glibert, P.M., Icarus Allen, J., Artioli, Y., Beusen, A., Bouwman, L., Harle, J., et al. (2014) Vulnerability of coastal ecosystems to changes in harmful algal bloom distribution in response to climate change: projections based on model analysis. Glob Change Biol 20: 3845-3858.

Gobler, C.J. (2020) Climate change and Harmful Algal Blooms: insights and perspective. Harmful Algae 91: 101731

Gobler, C.J., Doherty, O.M., Hattenrath-Lehmann, T.K., Griffith, A.W., Kang, Y., and Litaker, R.W. (2017) Ocean warming since 1982 has expanded the niche of toxic algal blooms in the North Atlantic and North Pacific oceans. Proc Natl Acad Sci 114: 4975-4980.

Goldberg, C.S., Strickler, K.M., and Fremier, A.K. (2018) Degradation and dispersion limit environmental DNA detection of rare amphibians in wetlands: Increasing efficacy of sampling designs. Sci Total Environ 633: 695-703.

This article is protected by copyright. All rights reserved. 
González-Pola, C. (2005) Intense warming and salinity modification of intermediate water masses in the southeastern corner of the Bay of Biscay for the period 1992-2003. J Geophys Res 110: C05020.

Granéli, E., Vidyarathna, N.K., Funari, E., Cumaranatunga, P.R.T., and Scenati, R. (2011) Can increases in temperature stimulate blooms of the toxic benthic dinoflagellate Ostreopsis ovata? Harmful Algae 10: 165-172.

Hall, T.A. (1999) BioEdit: A user-friendly biological sequence alignment editor and analysis program for Windows 95/98/NT. Nucleic Acids Symp Ser 41: 95-98.

Hallegraeff, G.M. (1993) A review of Harmful Algal Blooms and their apparent global ncrease. Phycologia 32: 79-99.

Hallegraeff, G.M. (2010) Ocean climate change, phytoplankton community responses, and harmful algal blooms: a formidable predictive challenge. J Phycol 46: 220-235.

Hallegraeff, G.M. and Bolch, C.J. (1991) Transport of toxic dinoflagellate cysts via ships' ballast water. Mar Pollut Bull 22: 27-30.

Hargreaves, A.L., Samis, K.E., and Eckert, C.G. (2014) Are species' range limits simply niche limits writ large? A Review of transplant experiments beyond the range. Am Nat 183: 157-173.

Heisler, J., Glibert, P.M., Burkholder, J.M., Anderson, D.M., Cochlan, W., Dennison, W.C., et al. (2008) Eutrophication and harmful algal blooms: A scientific consensus. Harmful Algae 8: 3-13.

Holt, R.D. (2003) On the evolution ecology of species' ranges. Evol Ecol Res 5: 159-178.

Huang, H.-L., Shao, Q.-W., Zhu, X.-J., Luo, J., Meng, R., Zhou, C.-X., et al. (2019) Distribution of Karlodinium veneficum in the coastal region of Xiangshan Bay in the East China Sea, as detected by a real-time quantitative PCR assay of ribosomal ITS sequence. Harmful Algae 81: 65-76. Hutchinson, G.E. (1957) Concluding Remarks. Cold Spring Harb Symp Quant Biol 22: 415-427. Jauzein, C., Açaf, L., Accoroni, S., Asnaghi, V., Fricke, A., Hachani, M.A., et al. (2018) Optimization of sampling, cell collection and counting for the monitoring of benthic harmful algal blooms: Application to Ostreopsis spp. blooms in the Mediterranean Sea. Ecol Indic 91: 116-127.

This article is protected by copyright. All rights reserved. 
Jauzein, C., Fricke, A., Mangialajo, L., and Lemée, R. (2016) Sampling of Ostreopsis cf. ovata using artificial substrates: optimization of methods for the monitoring of benthic harmful algal blooms. Mar Pollut Bull 107: 300-304.

Jeffery, B., Barlow, T., Moizer, K., Paul, S., and Boyle, C. (2004) Amnesic shellfish poison. Food Chem Toxicol 42: 545-557.

Jerde, C.L., Mahon, A.R., Chadderton, W.L., and Lodge, D.M. (2011) "Sight-unseen" detection of rare aquatic species using environmental DNA: eDNA surveillance of rare aquatic species. Conserv Lett 4: 150-157.

Jeunen, G., Knapp, M., Spencer, H.G., Lamare, M.D., Taylor, H.R., Stat, M., et al. (2019) Environmental DNA (eDNA) metabarcoding reveals strong discrimination among diverse marine habitats connected by water movement. Mol Ecol Resour 19: 426-438.

Jönsson, B.F. and Watson, J.R. (2016) The timescales of global surface-ocean connectivity. Nat Commun 7: 11239.

Kibler, S.R., Tester, P.A., Kunkel, K.E., Moore, S.K., and Litaker, R.W. (2015) Effects of ocean warming on growth and distribution of dinoflagellates associated with ciguatera fish poisoning in the Caribbean. Ecol Model 316: 194-210.

Koutsikopoulos, C., Beillois, P., Leroy, C., and Taillefer, F. (1998) Temporal trends and spatial structures of the sea surface temperature in the Bay of Biscay. Oceanol Acta 21: 335-344.

Kudela, R.M. and Gobler, C.J. (2012) Harmful dinoflagellate blooms caused by Cochlodinium sp.: Global expansion and ecological strategies facilitating bloom formation. Harmful Algae 14: 71-86.

Lacoursière-Roussel, A. and Deiner, K. (2019) Environmental DNA is not the tool by itself. J Fish Biol.

Lance, R., Klymus, K., Richter, C., Guan, X., Farrington, H., Carr, M., et al. (2017) Experimental observations on the decay of environmental DNA from bighead and silver carps. Manag Biol Invasions 8: 343-359.

This article is protected by copyright. All rights reserved. 
Laza-Martinez, A., Orive, E., and Miguel, I. (2011) Morphological and genetic characterization of benthic dinoflagellates of the genera Coolia, Ostreopsis and Prorocentrum from the southeastern Bay of Biscay. Eur J Phycol 46: 45-65.

Lazure, P. and Dumas, F. (2008) An external-internal mode coupling for a 3D hydrodynamical model for applications at regional scale (MARS). Adv Water Resour 31: 233-250.

Lazure, P., Garnier, V., Dumas, F., Herry, C., and Chifflet, M. (2009) Development of a hydrodynamic model of the Bay of Biscay. Validation of hydrology. Cont Shelf Res 29: 985-997.

Lett, C., Verley, P., Mullon, C., Parada, C., Brochier, T., Penven, P., and Blanke, B. (2008) A Lagrangian tool for modelling ichthyoplankton dynamics. Environ Model Softw 23: 1210-1214.

Levitus, S. (2001) Anthropogenic warming of earth's climate system. Science 292: 267-270.

Levitus, S. (2000) Warming of the world ocean. Science 287: 2225-2229.

Lim, H.C., Leaw, C.P., Tan, T.H., Kon, N.F., Yek, L.H., Hii, K.S., et al. (2014) A bloom of Karlodinium australe (Gymnodiniales, Dinophyceae) associated with mass mortality of cage-cultured fishes in West Johor Strait, Malaysia. Harmful Algae 40: 51-62.

Lyard, F., Lefevre, F., Letellier, T., and Francis, O. (2006) Modelling the global ocean tides: modern insights from FES2004. Ocean Dyn 56: 394-415.

Mächler, E., Deiner, K., Steinmann, P., and Altermatt, F. (2014) Utility of environmental DNA for monitoring rare and indicator macroinvertebrate species. Freshw Sci 33: 1174-1183.

Mangialajo, L., Bertolotto, R., Cattaneo-Vietti, R., Chiantore, M., Grillo, C., Lemee, R., et al. (2008) The toxic benthic dinoflagellate Ostreopsis ovata: quantification of proliferation along the coastline of Genoa, Italy. Mar Pollut Bull 56: 1209-1214.

Mangialajo, L., Ganzin, N., Accoroni, S., Asnaghi, V., Blanfuné, A., Cabrini, M., et al. (2011) Trends in Ostreopsis proliferation along the Northern Mediterranean coasts. Toxicon 57: 408-420.

Masó, M., Fortuño, J.M., De Juan, S., and Demestre, M. (2016) Microfouling communities from pelagic and benthic marine plastic debris sampled across Mediterranean coastal waters. Sci Mar 80: 117-127.

This article is protected by copyright. All rights reserved. 
Masó, M., Garcés, E., Pagès, F., and Camp, J. (2003) Drifting plastic debris as a potential vector for dispersing Harmful Algal Bloom (HAB) species. Sci Mar 67: 107-111.

McLeod, D.J., Hallegraeff, G.M., Hosie, G.W., and Richardson, A.J. (2012) Climate-driven range expansion of the red-tide dinoflagellate Noctiluca scintillans into the Southern Ocean. J Plankton Res 34: 332-337.

McManus, M.A. and Woodson, C.B. (2012) Plankton distribution and ocean dispersal. J Exp Biol 215: 1008-1016.

Mitarai, S., Siegel, D.A., Watson, J.R., Dong, C., and McWilliams, J.C. (2009) Quantifying connectivity in the coastal ocean with application to the Southern California Bight. J Geophys Res 114: C10026.

Molines, J.M., Barnier, B., Penduff, T., Treguier, A.M., and Le Sommer, J. (2014) ORCA12.L46 climatological and interannual simulations forced with DFS4.4: GJM02 and MJM88. Drakkar Group Exp Rep GDRIDRAKKAR, 2014-03-19, pp. 1-49

Moore, S.K., Trainer, V.L., Mantua, N.J., Parker, M.S., Laws, E.A., Backer, L.C., and Fleming, L.E. (2008) Impacts of climate variability and future climate change on harmful algal blooms and human health. Environ Health 7: S4.

Nakada, M., Hatayama, Y., Ishikawa, A., Ajisaka, T., Sawayama, S., and Imai, I. (2018) Seasonal distribution of Gambierdiscus spp. in Wakasa Bay, the Sea of Japan, and antagonistic relationships with epiphytic pennate diatoms. Harmful Algae 76: 58-65.

Oberbeckmann, S., Löder, M.G.J., and Labrenz, M. (2015) Marine microplastic-associated biofilms - a review. Environ Chem 12: 551-562

Paerl, H.W. and Paul, V.J. (2012) Climate change: Links to global expansion of harmful cyanobacteria. Water Res 46: 1349-1363.

Palmer, C.J., Tsai, Y.L., Paszko-Kolva, C., Mayer, C., and Sangermano, L.R. (1993) Detection of Legionella species in sewage and ocean water by polymerase chain reaction, direct fluorescent- antibody, and plate culture methods. Appl Environ Microbio/ 59: 3618-3624.

This article is protected by copyright. All rights reserved. 
Parsons, M.L., Aligizaki, K., Bottein, M.-Y.D., Fraga, S., Morton, S.L., Penna, A., and Rhodes, L. (2012) Gambierdiscus and Ostreopsis: Reassessment of the state of knowledge of their taxonomy, geography, ecophysiology, and toxicology. Harmful Algae 14: 107-129.

Parsons, M.L., Brandt, A.L., Ellsworth, A., Leynse, A.K., Rains, L.K., and Anderson, D.M. (2017) Assessing the use of artificial substrates to monitor Gambierdiscus populations in the Florida Keys. Harmful Algae 68: 52-66.

Pavaux, A.-S., Berdalet, E., and Lemée, R. (2020) Chemical ecology of the benthic dinoflagellate genus Ostreopsis: review of progress and future directions. Front Mar Sci 7: 498.

Pearce, I., Marshall, J.M., and Hallegraeff, G.M. (2001) Toxic epiphytic dinoflagellates from East Coast Tasmania. Proc 9th Int Conf - Harmful Algal Blooms 54-57.

Penna, A., Battocchi, C., Capellacci, S., Fraga, S., Aligizaki, K., Lemée, R., and Vernesi, C. (2014) Mitochondrial, but not rDNA, genes fail to discriminate dinoflagellate species in the genus Ostreopsis. Harmful Algae 40: 40-50.

Penna, A., Bertozzini, E., Battocchi, C., Galluzzi, L., Giacobbe, M.G., Vila, M., et al. (2007) Monitoring of HAB species in the Mediterranean Sea through molecular methods. J Plankton Res 29: 19-38.

Penna, A., Fraga, S., Battocchi, C., Casabianca, S., Giacobbe, M.G., Riobó, P., and Vernesi, C. (2010) A phylogeographical study of the toxic benthic dinoflagellate genus Ostreopsis Schmidt. J Biogeogr 37: 830-841.

Penna, A., Fraga, S., Battocchi, C., Casabianca, S., Perini, F., Capellacci, S., et al. (2012) Genetic Diversity of the genus Ostreopsis Schmidt: phylogeographical considerations and molecular methodology applications for field detection in the Mediterranean Sea. Cryptogam Algol 33: 153-163.

Perry, A.L. (2005) Climate change and distribution shifts in marine fishes. Science 308: 1912-1915.

Peterson, A.T. ed. (2011) Ecological niches and geographic distributions, Princeton, N.J: Princeton University Press.

This article is protected by copyright. All rights reserved. 
Pezzolesi, L., Guerrini, F., Ciminiello, P., Dell'Aversano, C., lacovo, E.D., Fattorusso, E., et al. (2012) Influence of temperature and salinity on Ostreopsis cf. ovata growth and evaluation of toxin content through HR LC-MS and biological assays. Water Res 46: 82-92.

Pierce, D.W., Barnett, T.P., AchutaRao, K.M., Gleckler, P.J., Gregory, J.M., and Washington, W.M. (2006) Anthropogenic warming of the oceans: observations and model results. J Clim 19: 18731900.

Pistocchi, R., Pezzolesi, L., Guerrini, F., Vanucci, S., Dell'Aversano, C., and Fattorusso, E. (2011) A review on the effects of environmental conditions on growth and toxin production of Ostreopsis ovata. Toxicon 57: 421-428.

Pitcher, G.C. and Probyn, T.A. (2011) Anoxia in southern Benguela during the autumn of 2009 and its linkage to a bloom of the dinoflagellate Ceratium balechii. Harmful Algae 11: 23-32.

Planque, B., Beillois, P., Jégou, A.M., Lazure, P., Petitgas, P., and Puillat, I. (2003) Large-scale hydroclimatic variability in the Bay of Biscay: the 1990s in the context of interdecadal changes. ICES Mar Sci Symp 219: 61-70.

Polyakov, I.V., Bhatt, U.S., Simmons, H.L., Walsh, D., Walsh, J.E., and Zhang, X. (2005) Multidecadal variability of North Atlantic temperature and salinity during the twentieth century. J Clim 18: $4562-4581$

Pujolar, J.M., Schiavina, M., Di Franco, A., Melià, P., Guidetti, P., Gatto, M., et al. (2013) Understanding the effectiveness of marine protected areas using genetic connectivity patterns and Lagrangian simulations. Divers Distrib 19: 1531-1542.

Pulliam, H.R. (2000) On the relationship between niche and distribution. Ecol Lett 3: 349-361.

Pulliam, H.R. (1988) Sources, sinks, and population regulation. Am Nat 132: 652-661.

R Core Team (2019) R: A language and environment for statistical computing. R Found Stat Comput Vienna Austria.

This article is protected by copyright. All rights reserved. 
Ralston, D.K., Keafer, B.A., Brosnahan, M.L., and Anderson, D.M. (2014) Temperature dependence of an estuarine harmful algal bloom: resolving interannual variability in bloom dynamics using a degree-day approach. Limnol Oceanogr 59: 1112-1126.

Reisser, J., Shaw, J., Hallegraeff, G., Proietti, M., Barnes, D.K.A., Thums, M., et al. (2014) Millimetersized marine plastics: A new pelagic habitat for microorganisms and invertebrates. PLOS ONE 9: e100289.

Rhodes, L. (2011) World-wide occurrence of the toxic dinoflagellate genus Ostreopsis Schmidt. Toxicon 57: 400-407.

Rossi, V., Ser-Giacomi, E., López, C., and Hernández-García, E. (2014) Hydrodynamic provinces and oceanic connectivity from a transport network help designing marine reserves. Geophys Res Lett 41: 2883-2891.

Saba, V.S., Griffies, S.M., Anderson, W.G., Winton, M., Alexander, M.A., Delworth, T.L., et al. (2016) Enhanced warming of the Northwest Atlantic Ocean under climate change. J Geophys Res Oceans 121: 118-132.

Santos, M., Oliveira, P.B., Moita, M.T., David, H., Caeiro, M.F., Zingone, A., et al. (2019) Ocurrence of Ostreopsis in two temperate coastal bays (SW iberia): Insights from the plankton. Harmful Algae 86: 20-36.

Sassoubre, L.M., Yamahara, K.M., Gardner, L.D., Block, B.A., and Boehm, A.B. (2016) Quantification of environmental DNA (eDNA) shedding and decay rates for three marine fish. Environ Sci Technol 50: 10456-10464.

Sato, S., Nishimura, T., Uehara, K., Sakanari, H., Tawong, W., Hariganeya, N., et al. (2011) Phylogeography of Ostreopsis along West Pacific coast, with special reference to a novel clade from Japan. PLoS ONE 6: e27983.

Scalco, E., Brunet, C., Marino, F., Rossi, R., Soprano, V., Zingone, A., and Montresor, M. (2012) Growth and toxicity responses of Mediterranean Ostreopsis cf. ovata to seasonal irradiance and temperature conditions. Harmful Algae 17: 25-34.

This article is protected by copyright. All rights reserved. 
van Sebille, E., Griffies, S.M., Abernathey, R., Adams, T.P., Berloff, P., Biastoch, A., et al. (2018) Lagrangian ocean analysis: fundamentals and practices. Ocean Model 121: 49-75.

Sechet, V., Sibat, M., Chomérat, N., Nézan, E., Grossel, H., Lehebel-Peron, J.-B., et al. (2012) Ostreopsis cf. ovata in the French Mediterranean coast: molecular characterisation and toxin profile. Cryptogam Algol 33: 89-98.

Selina, M.S., Morozova, T.V., Vyshkvartsev, D.I., and Orlova, T.Yu. (2014) Seasonal dynamics and spatial distribution of epiphytic dinoflagellates in Peter the Great Bay (Sea of Japan) with special emphasis on Ostreopsis species. Harmful Algae 32: 1-10.

Seoane, S. and Siano, R. (2018) New limits of Ostreopsis distribution in the Bay of Biscay: a first report of Ostreopsis in Santander Bay, Cantabria (Northern Spain). Harmful Algae News 60: 10.

Sexton, J.P., McIntyre, P.J., Angert, A.L., and Rice, K.J. (2009) Evolution and ecology of species range limits. Annu Rev Ecol Evol Syst 40: 415-436.

Seymour, M., Durance, I., Cosby, B.J., Ransom-Jones, E., Deiner, K., Ormerod, S.J., et al. (2018) Acidity promotes degradation of multi-species environmental DNA in lotic mesocosms. Commun Biol 1: 4 .

Shears, N.T. and Ross, P.M. (2009) Blooms of benthic dinoflagellates of the genus Ostreopsis; an increasing and ecologically important phenomenon on temperate reefs in New Zealand and worldwide. Harmful Algae 8: 916-925.

Shogren, A.J., Tank, J.L., Andruszkiewicz, E., Olds, B., Mahon, A.R., Jerde, C.L., and Bolster, D. (2017) Controls on eDNA movement in streams: transport, retention, and resuspension. Sci Rep 7: 5065.

Smayda, T.J. (2007) Reflections on the ballast water dispersal-harmful algal bloom paradigm. Harmful Algae 6: 601-622.

Strickler, K.M., Fremier, A.K., and Goldberg, C.S. (2015) Quantifying effects of UV-B, temperature, and $\mathrm{pH}$ on eDNA degradation in aquatic microcosms. Biol Conserv 183: 85-92.

This article is protected by copyright. All rights reserved. 
Taberlet, P., Coissac, E., Hajibabaei, M., and Rieseberg, L.H. (2012) Environmental DNA. Mol Ecol 21: 1789-1793.

Tanimoto, Y., Yamaguchi, H., Yoshimatsu, T., Sato, S., and Adachi, M. (2013) Effects of temperature, salinity and their interaction on growth of toxic Ostreopsis sp. 1 and Ostreopsis sp. 6 (Dinophyceae) isolated from Japanese coastal waters. Fish Sci 79: 285-291.

Tawong, W., Nishimura, T., Sakanari, H., Sato, S., Yamaguchi, H., and Adachi, M. (2014) Distribution and molecular phylogeny of the dinoflagellate genus Ostreopsis in Thailand. Harmful Algae 37: $160-171$.

Tawong, W., Yoshimatsu, T., Yamaguchi, H., and Adachi, M. (2015) Effects of temperature, salinity and their interaction on growth of benthic dinoflagellates Ostreopsis spp. from Thailand. Harmful Algae 44: 37-45.

Tester, P.A., Kibler, S.R., Holland, W.C., Usup, G., Vandersea, M.W., Leaw, C.P., et al. (2014) Sampling harmful benthic dinoflagellates: comparison of artificial and natural substrate methods. Harmful Algae 39: 8-25.

Tester, P.A., Litaker, R.W., and Berdalet, E. (2020) Climate change and harmful benthic microalgae. Harmful Algae 91: 101655.

Thomas, M.K., Kremer, C.T., Klausmeier, C.A., and Litchman, E. (2012) A global pattern of thermal adaptation in marine phytoplankton. Science 338: 1085-1088.

Thompson, J.D., Higgins, D.G., and Gibson, T.J. (1994) CLUSTAL W: improving the sensitivity of progressive multiple sequence alignment through sequence weighting, position-specific gap penalties and weight matrix choice. Nucleic Acids Res 22: 4673-4680.

Thomsen, P.F. and Willerslev, E. (2015) Environmental DNA - An emerging tool in conservation for monitoring past and present biodiversity. Biol Conserv 183: 4-18.

Tichadou, L., Glaizal, M., Armengaud, A., Grossel, H., Lemée, R., Kantin, R., et al. (2010) Health impact of unicellular algae of the Ostreopsis genus blooms in the Mediterranean Sea: experience of 
the French Mediterranean coast surveillance network from 2006 to 2009. Clin Toxicol 48: 839844.

Totti, C., Accoroni, S., Cerino, F., Cucchiari, E., and Romagnoli, T. (2010) Ostreopsis ovata bloom along the Conero Riviera (northern Adriatic Sea): Relationships with environmental conditions and substrata. Harmful Algae 9: 233-239.

Treml, E.A., Halpin, P.N., Urban, D.L., and Pratson, L.F. (2008) Modeling population connectivity by ocean currents, a graph-theoretic approach for marine conservation. Landsc Ecol 23: 19-36.

Tubaro, A., Durando, P., Del Favero, G., Ansaldi, F., Icardi, G., Deeds, J.R., and Sosa, S. (2011) Case definitions for human poisonings postulated to palytoxins exposure. Toxicon 57: 478-495.

Uppala, S.M., KÅllberg, P.W., Simmons, A.J., Andrae, U., Bechtold, V.D.C., Fiorino, M., et al. (2005) The ERA-40 re-analysis. Q J R Meteorol Soc 131: 2961-3012.

Van Dolah, F.M. (2000) Marine algal toxins: origins, health effects, and their increased occurrence. Environ Health Perspect 108: 133-141.

Vandersea, M.W., Kibler, S.R., Tester, P.A., Holderied, K., Hondolero, D.E., Powell, K., et al. (2018) Environmental factors influencing the distribution and abundance of Alexandrium catenella in Kachemak bay and lower cook inlet, Alaska. Harmful Algae 77: 81-92.

Verma, A., Hoppenrath, M., Harwood, T., Brett, S., Rhodes, L., and Murray, S. (2016) Molecular phylogeny, morphology and toxigenicity of Ostreopsis cf. siamensis (Dinophyceae) from temperate south-east Australia: Merimbula Ostreopsis. Phycol Res 64: 146-159.

Vila, M., Abós-Herràndiz, R., Isern-Fontanet, J., Àlvarez, J., and Berdalet, E. (2016) Establishing the link between Ostreopsis cf. ovata blooms and human health impacts using ecology and epidemiology. Sci Mar 80: 107-115.

Vila, M., Garcés, E., and Masó, M. (2001) Potentially toxic epiphytic dinoflagellate assemblages on macroalgae in the NW Mediterranean. Aquat Microb Ecol 26: 51-60.

This article is protected by copyright. All rights reserved. 
Wells, M.L. and Karlson, B. (2018) Harmful Algal Blooms in a changing ocean. In Global Ecology and Oceanography of Harmful Algal Blooms. Glibert, P.M., Berdalet, E., Burford, M.A., Pitcher, G.C., and Zhou, M. (eds). Cham: Springer International Publishing, pp. 77-90.

Wells, M.L., Trainer, V.L., Smayda, T.J., Karlson, B.S.O., Trick, C.G., Kudela, R.M., et al. (2015) Harmful algal blooms and climate change: Learning from the past and present to forecast the future. Harmful Algae 49: 68-93.

Zettler, E.R., Mincer, T.J., and Amaral-Zettler, L.A. (2013) Life in the "Plastisphere": microbial communities on plastic marine debris. Environ Sci Technol 47: 7137-7146.

Zhang, H., Lu, S., Li, Y., Cen, J., Wang, H., Li, Q., and Nie, X. (2018) Morphology and molecular phylogeny of Ostreopsis cf. ovata and O. lenticularis (Dinophyceae) from Hainan Island, South China Sea: Ostreopsis spp. from Hainan Island. Phycol Res 66: 3-14.

Zingone, A., Escalera, L., Aligizaki, C., Fernandez-Tejedor, M., Montresor, M., Mozetič, P. et al., (2020) Toxic marine microalgae and noxious blooms in the Mediterranean Sea: A contribution to the Global HAB Status Report. Harmful Algae DOI: 10.1016/j.hal.2020.101843

This article is protected by copyright. All rights reserved. 


\begin{tabular}{|c|c|c|c|c|c|c|c|c|c|c|}
\hline \multirow[t]{5}{*}{ Site ID } & Country & Site locality & \multicolumn{2}{|c|}{ Coordinates } & \multirow{2}{*}{$\frac{\text { Sampling date }}{28 / 08 / 2018}$} & \multirow{2}{*}{$\begin{array}{l}\text { Habitat type } \\
\text { Rocky substrate/sandy bottom }\end{array}$} & \multirow{2}{*}{$\begin{array}{l}\text { Wave } \\
\text { exposure }\end{array}$} & \multirow{2}{*}{$\begin{array}{l}\text { Temperature } \\
\left({ }^{\circ} \mathrm{C}\right)\end{array}$} & \multirow{2}{*}{$\begin{array}{l}\begin{array}{l}\text { Salinity } \\
\text { (PSU) }\end{array} \\
35.0\end{array}$} & \multirow{2}{*}{$\begin{array}{l}\begin{array}{l}\text { Duration of artifical } \\
\text { substrate exposure }(\mathrm{h})\end{array} \\
24.3\end{array}$} \\
\hline & Spain & Comillas & $43.391687^{\circ} \mathrm{N}$ & $-4.288888^{\circ} \mathrm{E}$ & & & & & & \\
\hline & Spain & Santander & $43.469985^{\circ} \mathrm{N}$ & $-3.727045^{\circ} \mathrm{E}$ & 28/08/2018 & Rocky substrate & Medium & 21.1 & 34.8 & 24.5 \\
\hline & Spain & Castro & $43.375686^{\circ} \mathrm{N}$ & $-3.212714^{\circ} \mathrm{E}$ & $30 / 08 / 2018$ & Rocky substrate / sandy bottom & Low & 22.3 & 34.8 & 24.6 \\
\hline & Spain & Zierbena & $43.353911^{\circ} \mathrm{N}$ & $-3.078913^{\circ} \mathrm{E}$ & $30 / 08 / 2018$ & Rocky substrate / sandy bottom & Sheltered & 22.6 & 34.8 & 24.7 \\
\hline & Spain & Lekeitio & $43.363350^{\circ} \mathrm{N}$ & $-2.498764^{\circ} \mathrm{E}$ & $30 / 08 / 2018$ & Rocky substrate/sandy bottom & Medium & 23.5 & 32.0 & 24.6 \\
\hline & Spain & Mutriku & $43.309862^{\circ} \mathrm{N}$ & $-2.381035^{\circ} \mathrm{E}$ & $30 / 08 / 2018$ & Rocky substrate & Sheltered & 25.9 & 34.6 & 24.5 \\
\hline & Spain & San Sebastian & $43.319686^{\circ} \mathrm{N}$ & $-2.004416^{\circ} \mathrm{E}$ & $28 / 08 / 2018$ & Rocky substrate / sandy bottom & Sheltered & 24.9 & 34.8 & 24.0 \\
\hline & Spain & Hondarribia & $43.391588^{\circ} \mathrm{N}$ & $-1.790892^{\circ} \mathrm{E}$ & $28 / 08 / 2018$ & Rocky substrate & Medium & 23.7 & 34.2 & 24.3 \\
\hline & France & Hendaye & $43.380289^{\circ} \mathrm{N}$ & $-1.756551^{\circ} \mathrm{E}$ & $28 / 08 / 2018$ & Rocky substrate & Medium & 23.5 & 33.7 & NA \\
\hline & France & Plage Abbadia & $43.381051^{\circ} \mathrm{N}$ & $-1.733057^{\circ} \mathrm{E}$ & $28 / 08 / 2018$ & Rocky substrate & Low & 24.7 & 28.4 & NA \\
\hline & France & Saint-Jean-de-Luz Ouest & $43.396656^{\circ} \mathrm{N}$ & $-1.680425^{\circ} \mathrm{E}$ & $27 / 08 / 2018$ & Rocksy substrate / sandy bottom & Low & 23.3 & 32.5 & 26.8 \\
\hline & France & Saint-Jean-de-Luz Est & $43.398342^{\circ} \mathrm{N}$ & $-1.664600^{\circ} \mathrm{E}$ & $27 / 08 / 2018$ & Rocky substrate & Medium & 24.8 & 33.3 & 26.2 \\
\hline & France & Biarritz & $43.493184^{\circ} \mathrm{N}$ & $-1.549430^{\circ} \mathrm{E}$ & $30 / 08 / 2018$ & Rocky substrate / sandy bottom & High & 23.0 & 34.0 & 24.8 \\
\hline & France & Bayonne & $43.527494^{\circ} \mathrm{N}$ & $-1.524644^{\circ} \mathrm{E}$ & $30 / 08 / 2018$ & Rocky substrate / sandy bottom & High & 23.3 & 32.8 & 24.9 \\
\hline & France & Capbreton & $43.648780^{\circ} \mathrm{N}$ & $-1.446800^{\circ} \mathrm{E}$ & $30 / 08 / 2018$ & Rocky substrate / sandy bottom & High & 23.7 & 34.3 & 24.9 \\
\hline & France & Vieux-Boucau & $43.785063^{\circ} \mathrm{N}$ & $-1.413639^{\circ} \mathrm{E}$ & $01 / 09 / 2018$ & Estuary & Low & 23.8 & 6.8 & 24.7 \\
\hline & France & Contis-les-bains & $44.089298^{\circ} \mathrm{N}$ & $-1.325365^{\circ} \mathrm{E}$ & $01 / 09 / 2018$ & Estuary & High & 18.8 & 3.0 & 23.5 \\
\hline & France & Cap Ferret & $44.630290^{\circ} \mathrm{N}$ & $-1.243460^{\circ} \mathrm{E}$ & 03/09/2018 & Rocky substrate & High & 21.0 & 34.0 & 24.5 \\
\hline 19 & France & Le Tottoral & $45.482604^{\circ} \mathrm{N}$ & $-1.152316^{\circ} \mathrm{E}$ & $03 / 09 / 2018$ & Sandy & Sheltered & 20.0 & 36.0 & 24.0 \\
\hline 20 & France & Fouras & $46.003350^{\circ} \mathrm{N}$ & $-1.121211^{\circ} \mathrm{E}$ & 05/09/2018 & Sandy & Medium & 25.7 & 37.0 & 23.8 \\
\hline 21 & France & Ile de Ré (Fort du Groin) & $46.231126^{\circ} \mathrm{N}$ & $-1.411441^{\circ} \mathrm{E}$ & $05 / 09 / 2018$ & Rocky substrate / sandy bottom & Medium & 21.1 & 35.8 & 24.3 \\
\hline & France & Jard-sur-Mer & $46.408523^{\circ} \mathrm{N}$ & $-1.577400^{\circ} \mathrm{E}$ & 08/09/2018 & Rocky substrate / muddy bottom & Medium & 19.3 & 34.6 & 25.5 \\
\hline & France & Les Sables d'Olonne & $46.488590^{\circ} \mathrm{N}$ & $-1.799913^{\circ} \mathrm{E}$ & 08/09/2018 & Rocky substrate / muddy bottom & Medium & 16.1 & 35.2 & 25.5 \\
\hline & France & Le Prégneau & $46.628567^{\circ} \mathrm{N}$ & $-1.878315^{\circ} \mathrm{E}$ & 08/09/2018 & Rocky substrate / muddy bottom & Medium & 15.5 & 35.0 & 25.6 \\
\hline & France & La Caillaudière & $46.692708^{\circ} \mathrm{N}$ & $-1.968054^{\circ} \mathrm{E}$ & 08/09/2018 & Rocky substrate / muddy bottom & Medium & 14.0 & 35.1 & 25.5 \\
\hline & France & Noirmoutier & $47.026724^{\circ} \mathrm{N}$ & $-2.248401^{\circ} \mathrm{E}$ & $10 / 09 / 2018$ & Rocky substrate / sandy bottom & Low & 18.4 & 34.5 & 24.8 \\
\hline & France & Pornic & $47.101201^{\circ} \mathrm{N}$ & $-2.078190^{\circ} \mathrm{E}$ & $10 / 09 / 2018$ & Sandy & Medium & 20.6 & 34.9 & 24.8 \\
\hline & France & Pointe St Gildas & $47.131156^{\circ} \mathrm{N}$ & $-2.232927^{\circ} \mathrm{E}$ & $10 / 09 / 2018$ & Rocky substrate & Low & 20.5 & 34.5 & 24.9 \\
\hline & France & Lérat & $47.364712^{\circ} \mathrm{N}$ & $-2.531667^{\circ} \mathrm{E}$ & $12 / 09 / 2018$ & Rocky substrate / sandy bottom & Low & 17.5 & 35.0 & 24.0 \\
\hline & France & Ile du Béchet & $47.451917^{\circ} \mathrm{N}$ & $-2.495008^{\circ} \mathrm{E}$ & $12 / 09 / 2018$ & Rocky substrate & Low & 20.7 & 35.2 & 23.3 \\
\hline & France & Damgan & $47.515778^{\circ} \mathrm{N}$ & $-2.577584^{\circ} \mathrm{E}$ & $12 / 09 / 2018$ & Rocky substrate / muddy bottom & Low & 20.0 & 24.8 & 23.4 \\
\hline & rance & Lorient & $47.698625^{\circ} \mathrm{N}$ & $-3.441273^{\circ} \mathrm{E}$ & $14 / 09 / 2018$ & Rocky substrate & Sheltered & 18.5 & 35.2 & 23.7 \\
\hline & France & Concarneau & $47.860375^{\circ} \mathrm{N}$ & $-3.914161^{\circ} \mathrm{E}$ & $14 / 09 / 2018$ & Rocky substrate / sandy bottom & Medium & 18.1 & 34.9 & 24.0 \\
\hline & France & Douarnenez-Tréboul & $48.102643^{\circ} \mathrm{N}$ & $-4.348145^{\circ} \mathrm{E}$ & $16 / 09 / 2018$ & Rocky substrate & Low & 16.5 & 35.4 & 24.2 \\
\hline & France & Crozon-Raguenez & $48.228184^{\circ} \mathrm{N}$ & $-4.433185^{\circ} \mathrm{E}$ & $16 / 09 / 2018$ & Rocky substrate / sandy bottom & Medium & 17.6 & 35.3 & 24.2 \\
\hline & France & Roscanvel & $48.312875^{\circ} \mathrm{N}$ & $-4.546529^{\circ} \mathrm{E}$ & $16 / 09 / 2018$ & Rocky substrate & Low & 17.3 & 35.3 & 24.2 \\
\hline 3 & France & Plougonvelin & $48.348803^{\circ} \mathrm{N}$ & $-4.699510^{\circ} \mathrm{E}$ & $18 / 09 / 2018$ & Rocky substrate & Medium & 16.3 & 35.2 & 24.9 \\
\hline & France & St Anne & $48.361506^{\circ} \mathrm{N}$ & $-4.551664^{\circ} \mathrm{E}$ & $18 / 09 / 2018$ & Rocky substrate & Sheltered & 17.5 & 35.8 & 24.7 \\
\hline & France & Plouguerneau & $48.626055^{\circ} \mathrm{N}$ & $-4.511130^{\circ} \mathrm{E}$ & $20 / 09 / 2018$ & Rocky substrate & Medium & 15.0 & 31.5 & 24.0 \\
\hline 0 & France & Roscoff & $48.728051^{\circ} \mathrm{N}$ & $-3.986287^{\circ} \mathrm{E}$ & 20/09/2018 & Rocky substrate & Low & 16.8 & 35.4 & 24.1 \\
\hline
\end{tabular}

This article is protected by copyright. All rights reserved. 


\begin{tabular}{|c|c|c|c|c|c|c|}
\hline (1)ol- ed strain ID & $\begin{array}{l}\text { Number of } \\
\text { isolated strains }\end{array}$ & $\begin{array}{l}\text { Site } \\
\text { ID }\end{array}$ & Isolation locality & Accession number & $\begin{array}{l}\text { Highest similar sequence } \\
\text { after nucleotide blast }\end{array}$ & Identified species \\
\hline $\begin{array}{l}\text { B1, SB3, SB4, SB5, SC1, SC2, } \\
\text { C5, SD3, SD4, SD5, SD6 }\end{array}$ & 11 & 2 & Santander & $\begin{array}{l}\text { MT952006; MT952007; MT952008; MT952009; } \\
\text { MT952010; MT952011; MT952012; MT952015; } \\
\text { MT952016; MT952017; MT952018 }\end{array}$ & KT868527.1 & Ostreopsis cf. siamensis \\
\hline SD2 & 2 & 2 & Santander & MT952013; MT952014 & MH790464.1 & Ostreopsis cf. siamensis \\
\hline (C11) & 8 & 3 & Castro & $\begin{array}{l}\text { MT952059; MT952060; MT952061; MT952063; } \\
\text { MT952065; MT952066; MT952067; MT952068 }\end{array}$ & КT868527.1 & Ostreopsis cf. siamensis \\
\hline & 2 & 3 & Castro & MT952058; MT952062 & MH790464.1 & Ostreopsis cf. siamensis \\
\hline & 1 & 3 & Castro & MT952064 & MH478526.1 & Ostreopsis cf. siamensis \\
\hline $\mathrm{Z1}, \angle 2, \mathrm{Z3}, \mathrm{Z4}, \mathrm{Z5}, \mathrm{Z7}, \mathrm{Z8}$ & 7 & 4 & Zierbena & $\begin{array}{l}\text { MT952050; MT952051; MT952052; MT952053; } \\
\text { MT952054; MT952056; MT952057 }\end{array}$ & КT868527.1 & Ostreopsis cf. siamensis \\
\hline & 1 & 4 & Zierbena & MT952055 & MH790464.1 & Ostreopsis cf. siamensis \\
\hline & 1 & 5 & Lekeitio & MT952035 & MH478526.1 & Ostreopsis cf. siamensis \\
\hline LD3 & 1 & 5 & Lekeitio & MT952036 & KT868527.1 & Ostreopsis cf. siamensis \\
\hline MC3 & 1 & 6 & Mutriku & MT952069 & KT868527.1 & Ostreopsis cf. siamensis \\
\hline $\begin{array}{l}\text { D2, D3, D4, D5, D7, D8, D9, } \\
\text { D10, } 11, \mathrm{D} 12, \mathrm{D} 13, \mathrm{D} 14 \\
\mathrm{D} 16\end{array}$ & 14 & 7 & San Sebastian & $\begin{array}{l}\text { MT952019; MT952020; MT952021; MT952022; } \\
\text { MT952024; MT952025; MT952026; MT952027; } \\
\text { MT952028; MT952029; MT952030; MT952031; } \\
\text { MT952033; MT952034 }\end{array}$ & KT868527.1 & Ostreopsis cf. siamensis \\
\hline & 2 & 7 & San Sebastian & MT952023; MT952032 & MH478526.1 & Ostreopsis cf. siamensis \\
\hline H12, 313 & 9 & 8 & Hondarribia & $\begin{array}{l}\text { MT952038; MT952039; MT952040; MT952042; } \\
\text { MT952043; MT952044; MT952045; MT952048; } \\
\text { MT952049 }\end{array}$ & KT868527.1 & Ostreopsis cf. siamensis \\
\hline$(11, \mathrm{i}: \mathrm{H} 10$ & 3 & 8 & Hondarribia & MT952037; MT952041; MT952046 & MH790464.1 & Ostreopsis cf. siamensis \\
\hline H11 ) & 1 & 8 & Hondarribia & MT952047 & MH478526.1 & Ostreopsis cf. siamensis \\
\hline
\end{tabular}

This article is protected by copyright. All rights reserved. 


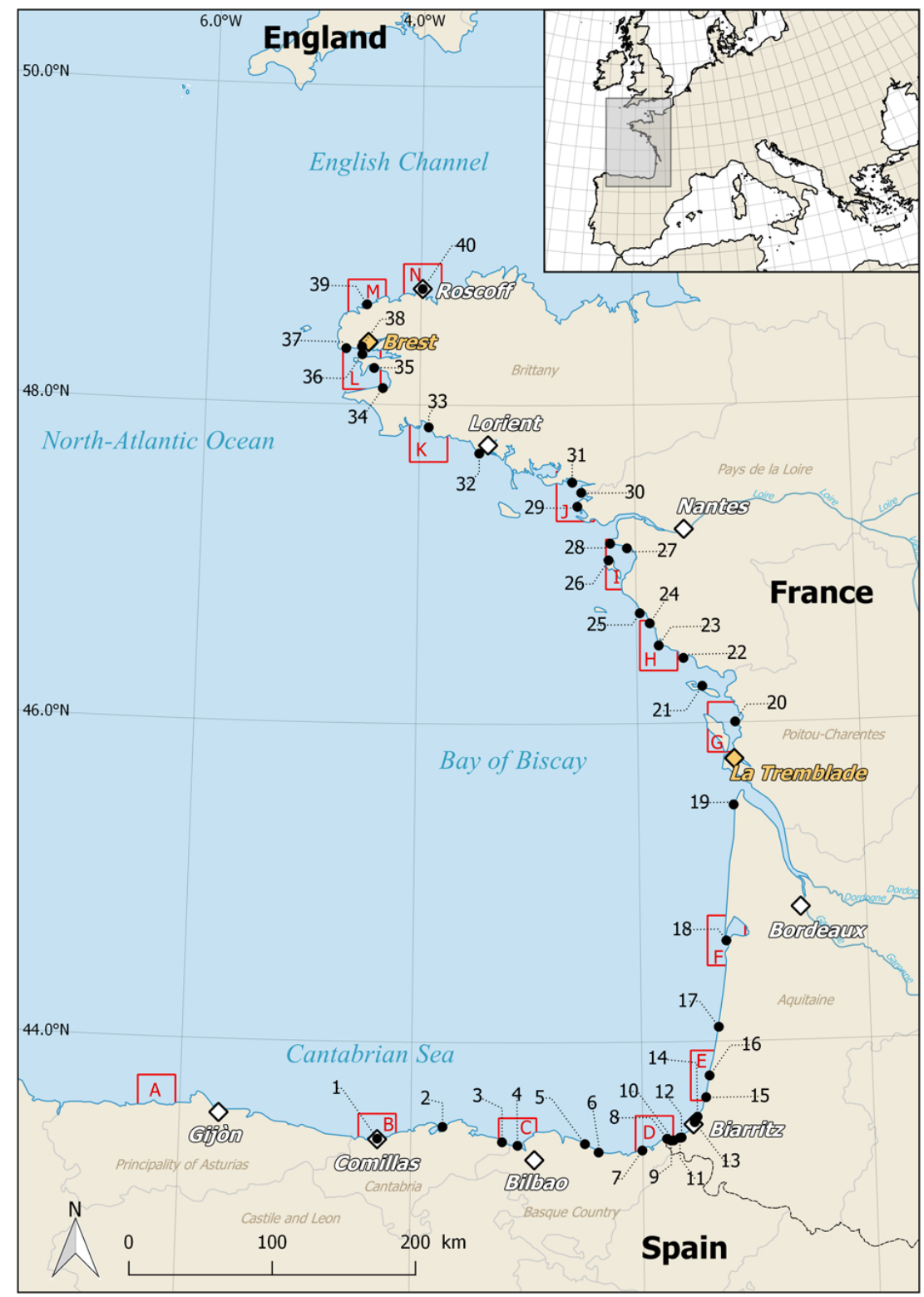

Figure 1: Map of the study area and sampling sites along the Bay of Biscay during the 2018 sampling campaign. Black points represent the 40 sites sampled during the campaign. Red frames represent the areas used for connectivity analyses. Orange squares represent the two sites used for plastic polymer temporal sampling.

$80 \times 113 \mathrm{~mm}(300 \times 300 \mathrm{DPI})$ 


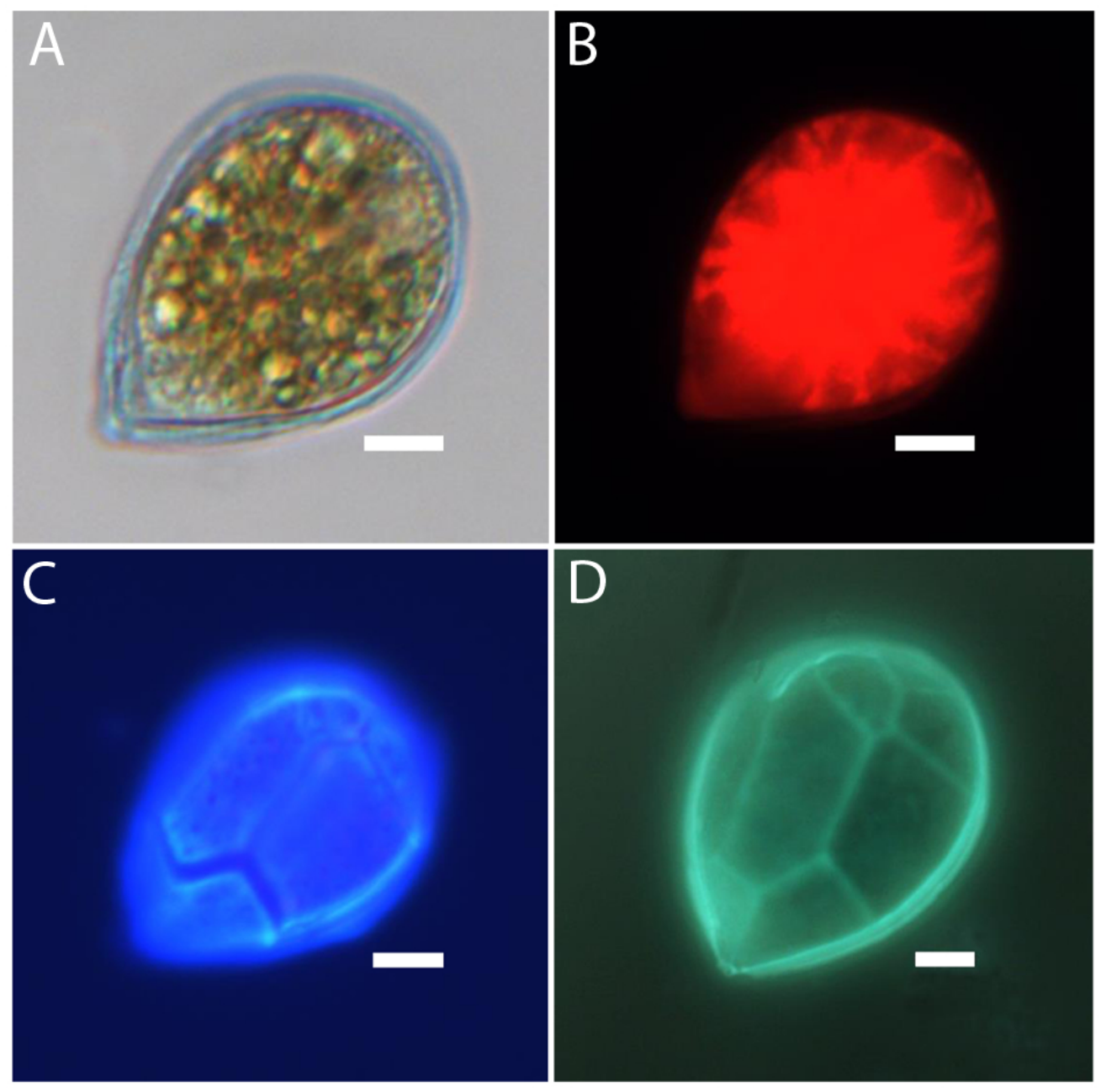

Figure 2: Micrographs of the same cell of Ostreopsis cf. siamensis in apical view from strain Z1 (Genbank accession number: MT952050) isolated in this study in light microscopy (A) and in epifluorescence microscopy under respectively green and UV-light illumination to highlight chloroplasts (B) or thecal plates (C, Calcofluor white-stained cell). D) Cell collected from macroalgae sample at site 12 (Saint-Jean de Luz Est) under UV-light (Solophenyl Flavine-stained cell). Scale bars $=10 \mu \mathrm{m}$. 

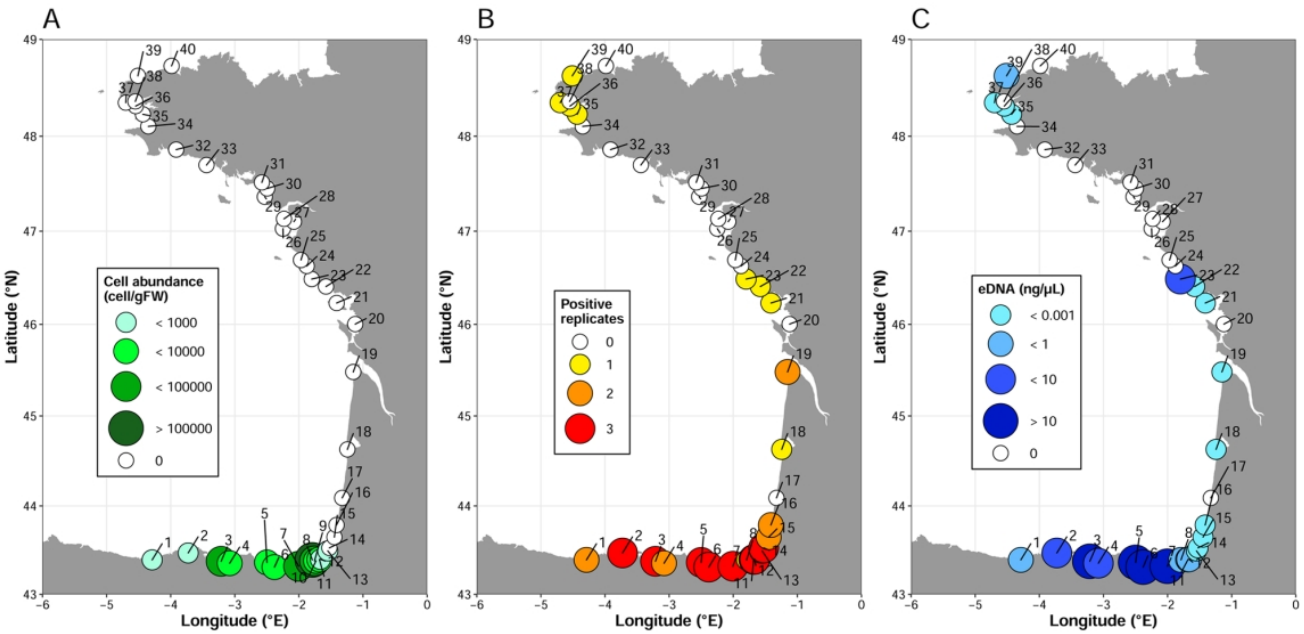

Figure 4: Spatial distribution of Ostreopsis cf. siamensis in the Bay of Biscay. Abundance of epiphytic cells assessed by light microscopy counting (A). eDNA detection (B) and estimation (C) of O. cf. siamensis assessed by qPCR analyses. 


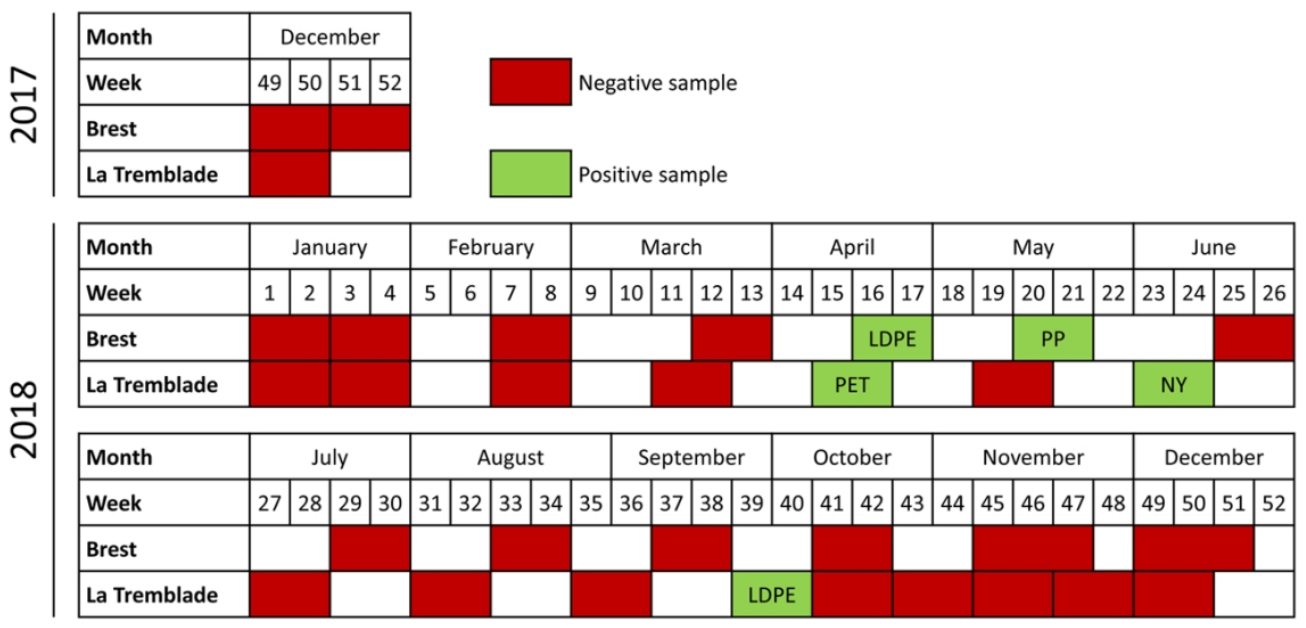

Figure 5: Temporal distribution of Ostreopsis cf. siamensis inferred from environmental DNA analyses carried out on plastic polymer substrates collected in 2017 and 2018 in Brest and La Tremblade. Plastic polymer substrates were immersed for two weeks, indicated with number for each year. Positive detection corresponds to the validation of $O$. cf. siamensis sequence from qPCR products. The type of polymer substrate of positive samples is indicated $(\mathrm{LDPE}=$ Low Density Polyethylene; $\mathrm{PP}=$ Polypropylene; $\mathrm{PET}=$ Polyethylene Terephtalate; NY = Nylon). 
